\title{
Hermetyzm
}

\section{DICTA HERMETIS \\ W MANUSKRYPCIE BIERNATA \\ Z LUBLINA}

\author{
TOMASZ SÓJKA ${ }^{1}$ \\ (Uniwersytet im. Adama Mickiewicza w Poznaniu)
}

Słowa kluczowe: pisma hermetyczne, hermetyzm, humanizm, Biernat z Lublina, manuskrypt

Key words: hermetic writings, hermetism, humanism, Biernat of Lublin, manuscript

\begin{abstract}
Abstrakt: Tomasz Sójka, DICTA HERMETIS W MANUSKRYPCIE BIERNATA Z LUBLINA. „PORÓWNANIA" XVII (2015). T. XVII. S. 165-196. ISSN 17330-165X. Prezentowana publikacja jest efektem badań nad tradycją hermetyczną i początkami polskiego humanizmu. Omawia tekstualną zawartość pierwszej z trzech części rękopisu PAN nr 1717 z Krakowa, w którym Biernat z Lublina spisał wybrane fragmenty pism hermetycznych. Artykuł ukazuje wnioski, jakie pojawiają się na kolejnych etapach analizy filologicznej. Procedura interpretacyjna skupia się na podstawowych zagadnieniach hermetycznych. Wskazuje na dominanty tematyczne wybrane do manuskryptu lub celowo pominięte przez Biernata z Lublina. Oprócz tego zestawia wybrane edycje pism hermetycznych, porównuje konkretne fragmenty, zdania i pojedyncze słowa (dicta Hermetis). Egzegeza ukazuje także filozoficzną tradycję, która warunkowała sposób czytania przez Biernata z Lublina.
\end{abstract}

Abstract: Tomasz Sójka, DICTA HERMETIS IN THE MANUSCRIPT OF BIERNAT OF LUBLIN. "PORÓWNANIA" 17 (2015). Vol. XVII. P. 165-196. ISSN 17330-165X. This publication is the effect of research on the hermetic tradition and the beginning of the Polish humanism. It examines the textual content of the first of the three parts of the manuscript PAN No 1717 from Crakow, in which Biernat of Lublin wrote down selected fragments of hermetic writings. The article shows conclusions that appear on different stages of the philological analysis. The inter-

\footnotetext{
${ }^{1}$ Correspondence Address: sojkowski@wp.pl
} 
pretative procedure focuses on fundamental hermetic issues. It indicates dominant topics that were chosen and copied into the manuscript or purposely omitted by Biernat of Lublin. Moreover, it combines selected editions of hermetic writings, compares specific fragments, sentences and words (dicta Hermetis). This exegesis also reveals the philosophical tradition that influenced the way of reading by Biernat of Lublin.

Europejski humanizm jest ściśle związany z odkryciami i reinterpretacją tekstów antycznych. Tezę tę warto wielokrotnie powtarzać, szczególnie że nieustannie powstają różne sposoby rozumienia pojęcia humanitas, a sam humanizm zmienia swe upostaciowanie wśród odmiennych kontekstów i nurtów kulturowych (Nowicka-Jeżowa 12-123). Na przełomie XV i XVI wieku pisma starożytne stanowiły filozoficzny i filologiczny fundament dla rozumienia kondycji człowieka. Dzięki temu ożywiła się równocześnie myśl humanistyczna, co przejawiało się niemal w każdym ośrodku intelektualnym Europy. Na polskim obszarze konkretnym tego przykładem jest między innymi manuskrypt, $\mathrm{w}$ którym polski poeta i tłumacz Biernat $\mathrm{z}$ Lublina ${ }^{2}$ zawarł wybrane sentencje $\mathrm{z}$ pism legendarnego Hermesa Trismegistosa, Platona oraz Arystotelesa ${ }^{3}$. Powstanie takiej antologii warunkowały różne tendencje i zjawiska kulturowe charakterystyczne dla wczesnego renesansu. Manuskrypt zaistniał oczywiście dzięki indywidualnym zdolnościom Biernata z Lublina, lecz także dzięki rozwojowi nauk filologicznych, zwiększaniu kompetencji uniwersyteckich, wzrostowi znaczenia kultury dworskiej, sprawnej wymianie myśli (podróże europejskich humanistów, spotkania soborowe, transmisja tekstów, rozwój druku). Wszystkie te elementy przyczyniły się do tego, że w Polsce interesowano się różnymi nurtami intelektualnymi, wśród których znalazł się również hermetyzm.

Na uwagę zasługuje oczywiście każda część antologii Biernata: zarówno pisma Arystotelesa (A, 157-222v), Platona (A, 36-157) oraz Hermesa Trismegistosa (A, 1-35v). W prezentowanym artykule skupiam się jednak wyłącznie na części hermetycznej. Wnioski wyprowadzam zawsze z pierwszego zasadniczego pytania: jaka jest recepcja pism hermetycznych w manuskrypcie Biernata z Lublina? Procedurę interpretacyjną uzależniam od wskazanej na każdym etapie dominanty tematycznej. „Drobiazgowa konfrontacja ze źródłem” (Domański 2008: 381) stanowi tutaj punkt wyjścia dla każdego kolejnego stopnia egzegezy. Pod tym względem staram się kontynuować sposób pracy nad tym manuskryptem, który zainicjował Juliusz Domański, a rozwinął Janusz S. Gruchała (Gruchała 63-81).

2 Patrz: Brückner 1902; Biernat z Lublina 1910; Ziomek 1953; Freedman 1985; Biernat z Lublina 1997.

${ }^{3}$ Patrz wykaz skrótów: A. 
Biernat z Lublina wybrał do pierwszej części swojej antologii sentencje $\mathrm{z}$ dwóch najważniejszych zbiorów hermetycznych: De divina voluntate (obecnie najczęściej tytułowany Asclepius ${ }^{4}$ ) oraz De potestate et sapientia Dei (nazywany także Pimander - łacińskie tłumaczenie traktatów tytułowanych Corpus hermeticum). Nieznany jest konkretny egzemplarz tego ostatniego, który stanowił podstawę dla rękopisu Biernata. W manuskrypcie nie ma żadnych śladów, wskazujących na to, że Biernat badał także grecki oryginał. Można stwierdzić jednoznacznie, że czytał ten tekst jedynie z łacińskiego przekładu Marsilia Ficina. Do 1505 roku powstało osiem edycji Pimandra: Treviso 1471; Ferrara 1472; Wenecja 1481, 1491, 1493; Paryż 1494; Moguncja 1503; Paryż 15056. Dzięki żywiołowemu rozwojowi drukarstwa i zacieśniającej się współpracy z italskimi tłoczniami, jeden z egzemplarzy mógł też trafić do zamku w Smoleniu, gdzie Biernat opracowywał manuskrypt na dworze Pileckich?.

Asclepius bez wątpienia inspirował humanizm już w czasach średniowiecznych ${ }^{8}$. Trudno jednak powiedzieć, jak Biernat z Lublina po raz pierwszy zetknął się i z tym pismem. Po europejskich bibliotekach krążyło wówczas około osiemdziesięciu manuskryptów, w których umieszczono ten tekst, oraz czterokrotnie wznawiane druki ${ }^{9}$. Równocześnie z rękopisem Biernata powstawała edycja paryska, przy której współpracowali w oficynie Henryka Stephanusa Jakub Lefèvre d'Etaples i jego uczeń z Krakowa Jan Schilling ${ }^{10}$. Poza tym, Asclepiusa często cytowano w licznych traktatach filozoficznych. Być może Biernat miał dostęp do któregoś z rękopisów, chociażby do egzemplarza z Pragi11, zaginionego (lub wywie-

${ }^{4}$ Cytaty z Asclepiusa przywołuję z edycji rzymskiej (Editio Romana) z 1469 roku. Patrz wykaz skrótów: Ed. Rom. Odsyłam też do wydania krytycznego opracowanego przez Arthura Darby Nocka oraz Andrea Jean Festugière'a. Patrz wykaz skrótów: NF II. Polski przekład cytuję z edycji Kazimierza Pawłowskiego (Pseudo-Apulejusz 173-219). Tłumaczenie własne podpisuję inicjałami TS. Wszystkie podkreślenia w artykule odtwarzają podkreślenia z manuskryptu Biernata z Lublina.

${ }^{5}$ Taki też tytuł odnotował Biernat $\mathrm{z}$ Lublina na karcie 11v.

6 Patrz: Campanelli LXII-LXXXIV.

${ }^{7}$ Na karcie 30r po wypisach z De potestate et sapientia Dei umieścił zdanie: „Bernardus Lublinius in Pylca scripsit apud domum Ioannem tertium Pylcensem eius liberalitate otio non ignavo fruens". „Pisał to Biernat Lubelczyk w Pilczy, u pana Jana trzeciego Pileckiego, korzystając z jego łaskawości w niebezczynnym próżnowaniu". Cytat w tłumaczeniu polskim S. Grzeszczuka (Biernat z Lublina 1997: 14).

${ }^{8}$ Inspiracje te wielokrotnie już omawiano. W zwięzłym artykule przedstawił ten temat Paolo Lucentini (Lucentini 1992: 397-420).

${ }^{9}$ Listę manuskryptów oraz pierwszych edycji sporządzili P. Lucentini oraz V. Perrone Compagni (Lucentini, Compagni 2001: 11-18, 115).

10 Ta zbieżność dat pozwoliła też na pewne przypuszczenia na temat biografii Biernata z Lublina (Gruchała 71).

11 Patrz: Praha, Archiv Pražského Hradu, Metrop. Kapit. L. 94 (1348), sec. XIII, membr., ff. 39: $21 v-25 v$. 
zionego) manuskryptu z biblioteki Macieja z Miechowa12 lub, być może, ze zbiorów Kallimacha, zanim jeszcze uległy spaleniu. Jednakże przy tworzeniu swojej antologii Biernat niemal wiernie kopiował z Editione Romana ${ }^{13}$ lub z edycji na niej wzorowanej. Swoje wypisy zatytułował na pierwszej karcie Ex Mercurio Trismegisto de divina voluntate sententie, co także wskazuje na podobieństwo $\mathrm{z}$ recepcją $\mathrm{w}$ renesansowej Italii. Można również w manuskrypcie Biernata doszukiwać się bezpośrednich wpływów lub inspiracji płynących z florenckiej nauki prisca theologia i pia philosophia, lecz ślady Biernatowej lektury naprowadzają kilkakrotnie na odmienne przekonania filozoficzne, o czym dokładniej powiem w dalszej części analizy.

Biernat z Lublina nie uwzględnił dialogicznej formy pism hermetycznych. Nie uwyraźnił $\mathrm{w}$ ten sposób objawieniowego charakteru wypowiedzi oraz napięcia, jakie niekiedy wynika w dyskusji Hermesa Trismegistosa z jego uczniami. Dicta Hermetis w manuskrypcie Biernata mają postać adagiów, które pozwalają szybko orientować się pośród hermetycznych treści ${ }^{14}$.

Jednakże wystarczy tylko pobieżny przegląd Biernatowej antologii, by zauważyć, że polski filozof traktował hermetyzm jako tekstualną matrycę dla idei humanistycznych. I mimo że autor omawianej antologii nie aspirował do stworzenia żadnego scholastycznego komentarza, nie przeprowadził wyjaśniającej egzegezy, nie przemycał też wątków hermetycznych do swojej poezji, to jednak możemy mówić o jego wyraźnie określonym odbiorze. Biernat, czytając teksty hermetyczne, przepisywał do swojej antologii wybrane sentencje, podkreślał istotne dla siebie fragmenty, jednocześnie czynił notatki na marginesie i tworzył indeks słów oraz zagadnień wspólnych dla różnych partii tekstu. Selekcja ta jest bardzo dokładna, a jednocześnie bardzo ostrożna, choć na pierwszy rzut oka można odnieść wrażenie, że Biernat z Lublina rozpraszał zawartość tekstualną, rozdzielał i łączył motywy, akcentował sprzeczności, uwypuklał treściowe zróżnicowanie, a przy tym nie sugerował konkluzji. Sam Asclepius niejako podsuwa taki sposób odczytania. Filozoficzne motywy w nim zawarte są luźno porozrzucane po całym tekście. Hermes Trismegistos, prowadząc swój objawieniowy wykład przed Asklepiusem, Thatem i Ammonem, swobodnie przechodzi pomiędzy zagadnieniami ontologicznymi, teologicznymi, etycznymi, eschatologicznymi.

Przyjrzyjmy się wypisom z łacińskiego przekładu Corpus hermeticum i z Asclepiusa, koncentrując uwagę na tematach związanych $\mathrm{z}$ wiedzą o Bogu, świecie i człowieku. Już sam indeks ${ }^{15}$ antologii Biernata w przeważającej mierze koncentruje się wokól tych dicta Hermetis. Podkreślenie na karcie 23r - „Mundus deo, ho-

12 Por: Hajdukiewicz 304-305.

13 Patrz: przypis nr 42.

${ }^{14}$ Jeden tylko raz przepisał Biernat dicta $\mathrm{w}$ formie dialogu na karcie 3v, gdy odnotował początek z Ascl. XIV.

${ }^{15} \mathrm{~W}$ indeksie antologii odnotował między innymi hasła: deus gubernatorem; dei nominatio; essentia dei; deus omnia; generatio; motus; mundus fertus; homo verus; imago dei homo; homo malus; homo melior angelis. 
$\underline{\text { mo mundo, homini brutum subiciuntur }}{ }^{16 "}$ (Campanelli ed., 69.234-235) - wskazuje, że Biernat przywiązywał szczególną wagę do hermetycznego wykładu o hierarchicznym porządku duchowo-materialnym. Porządek ten w tekstach hermetycznych został opisany liczną grupą pojęć oraz poetyckich metafor, które przez setki lat przenikały do europejskiego piśmiennictwa.

\section{Sermo divinus}

Na wstępie Asclepiusa Hermes Trismegistos zaprasza swoich uczniów do rozmowy - rozmowy uświęconej i boskiej (sermo divinus). I w rzeczy samej, treści dotyczące Boga najwyższego (summus deus), bogów (dii terreni), boskości (deitas), siły boskiej (numen), pobożności (pietas), religijnego postępowania (via divina), a także idolatrii to stałe tematy poruszane $\mathrm{w}$ dialogach hermetycznych. Owe dicta Hermetis wielokrotnie wzbudzały liczne kontrowersje, jak również ugruntowywały filozoficzne konsensusy. Jak wygląda natomiast teologia hermetyczna zapisana na kartach Biernatowej antologii? W jaki sposób Biernat z Lublina przeczytał i odnotował passusy mówiące o Bogu oraz o umiejętności postrzegania tego, co boskie (sensus divinitatis)? Tematy te otwierają manuskrypt Biernata na tych kartach, na których przeprowadził on najuważniejszą selekcję zdań.

Unitas dei. W X rozdziale Asclepiusa Hermes Trismegistos w ten sposób rozpoczyna swój wykład: „Eternitatis dominus deus primus. Secundus est mundus. Homo est tertius. Effector mundi deus \& eorum que insunt omnium. Simul cuncta gubernando cum ipso homine gubernatore composita ${ }^{17 "}$ (Ed. Rom., 151r.11-14; A, 2r). Autor antologii zachowywał hermetyczny wykład o trójcy „Bóg, świat i człowiek" bardzo przezornie. Przepisał bowiem powyższe sentencje oraz korespondujący z nimi rozdział XXXII, jak również podobne zdania z C. H. X.1418, jednakże całkowicie wykluczył opis wszechświata jako przebóstwionego uniwersum, czyli jako „drugiego boga” (deus secundus) zrodzonego z najwyższego Stwórcy wszechrzeczy (Dominus \& omnium conformator; summus Deus). Pominął niemal zupełnie (oprócz ostatniego zdania) słynny - dzięki Laktancjuszowi, średniowiecznym filozofom i inskrypcji w katedrze w Sienie - passus z VIII rozdziału Asclepiusa. Przypomnijmy ${ }^{19}$ :

16 „Bogu podlega świat, światu człowiek, a człowiekowi stworzenia bezrozumne” (TS). Patrz: C. H. X.22.

17 Por.: Ascl. X (NF II, 308.7-11). „Pan wieczności, bóg - jest pierwszy. Drugi jest świat. Trzeci jest człowiek. Stwórca świata i wszystkiego, co w nim się znajduje, bóg zarządza wszystkim wespół z człowiekiem, współwładcą tego, co zostało stworzone" (Pseudo-Apulejusz 183).

${ }^{18} \mathrm{Na}$ karcie 22r: „Tria igitur sunt heac, deus pater bonum \& mundus, \& homo” (Campanelli ed. 70.143-144). „Oto więc trójca: Bóg ojciec Dobro oraz świat i człowiek” (TS).

${ }^{19}$ Filozoficzną inspiracją dla anonimowego autora tego wykładu były w starożytności niektóre wątki platońskie, stoickie oraz judaistyczne. Por: (Scott 1985c: 46-48). 
Audi ergo Asclepi. Dominus \& omnium conformator, quem recte deum dicimus, quem a se secundum fecerit, qui videri \& sentiri possit. Eundem secundum sensibilem ita dixerim, non ideo quod ipse sentiat, de hoc enim an ipse sentiat, an non alio dicemus tempore, sed eo quod videntium sensus incurrit. Quoniam ergo hunc fecit ex se primum \& a se secundum, visusque est ei pulcher utpote qui sit omnium bonitate plenissimus, amavit eum, ut divinitatis sue parte, \& tam bonus esset voluit alium, qui illum, quem ex se fecerat, intueri potuisset. Simulque \& rationis imitatorem \& diligentie fecit hominem (Ed. Rom., 150r.36-38-150v. 1-7) ${ }^{20}$.

Biernat z Lublina nie tylko nie uwzględnił powyższego wykładu, lecz także korespondujących z nim fragmentów z C. H. VIII.3, gdzie świat-uniwersum jako "drugi bóg" posiada sferyczną budowę (Campanelli ed., 50.28-40), pominął także wykład o sferycznej budowie wszechświata z C. H. I.25-26 (Campanelli ed., 16-17.203-218); nie przepisał również zdań z C. H. IX.8, gdzie czytamy „cosmus quidem dei filius 21" (Campanelli ed., 56.87-88). Co więcej, konsekwentnie opuszczał podobne fragmenty w dalszych częściach Asclepiusa, w których Hermes Trismegistos opisuje „bogów poznawalnych zmysłami” - „dei sensibiles” (Ed. Rom., 153r.25-26)22. Z III rozdziału Corpus hermeticum odnotował niemal w całości passus o stworzeniu świata, lecz pominął stamtąd sentencje o wielości bóstw ${ }^{23}$. Nie uwzględnił również zdania z C. H. X.5 o bogach Uranosie i Kronosie jako „naszych prastwórcach"24" - "Celus ac Saturnus nostri progenitores” (Campanelli ed., 61.46-47). Nie zawarł także wykładu na temat Jowisza Plutońskiego - „Iupiter Plutonius” (Ed. Rom., 155v.37-38-156r.1-2) ${ }^{25}$ - oraz nauki o źródłosłowie miejsca zwanego „Hadesem” (Ed. Rom., 152v.35-38-153r.1-2)26, pominął też alegoryzowanie prokreacyjnej mocy natury pod postacią Kupidyna i Wenery (Ed. Rom.,

${ }^{20}$ Por: Ascl. VIII (NF II, 304.20-305.1-12). „Słuchaj zatem, Asklepiuszu: Pan i twórca wszystkich rzeczy, którego słusznie nazywamy bogiem, stworzył następnego po sobie boga, którego można zobaczyć i usłyszeć. Tego drugiego nazywamy zmysłowym, ale nie dlatego, że dysponuje jakoby on poznaniem zmysłowym (o tym bowiem, czy dysponuje on poznaniem zmysłowym czy nie, powiemy $\mathrm{w}$ innym czasie) lecz dlatego, że sam podpada pod zmysły istot obdarzonych wzrokiem. Ponieważ stworzył go jako pierwszy byt po sobie i sobie najbliższy, a wydał mu się piękny jako najbardziej przepełniony dobrocią ze wszystkich stworzeń, przeto pokochał go jako owoc swojej własnej boskości. A ponieważ bóg jest tak wielki i tak dobry, zapragnął jeszcze kogoś, kto by tego drugiego, którego stworzył z siebie, mógł oglądać. W ten sposób stworzył człowieka, jako jego naśladowcę zarówno co do rozumności, jak i sumienności" (Pseudo-Apulejusz 181).

21 "Kosmos to syn Boga” (TS).

22 Por: Ascl. XIX (NF II, 318.18-19); (Pseudo-Apulejusz 193).

${ }^{23}$ Nie przepisał zdania "Quisque deorum ex interna virtute ascriptum sibi opus explevit" (Campanelli ed., 28.19-20). „Każdy spośród bogów wypełnił swe zadanie, do którego wewnętrzną mocą został wyznaczony" (TS). Patrz: C. H. III.3.

24 "Celus ac Saturnus nostri progenitores" (Campanelli ed., 61.46-47).

25 Por: Ascl. XXVII (NF II, 332.12-17); (Pseudo-Apulejusz 204).

26 Por: Ascl. XVII (NF II, 316.14-17-317.1-5); (Pseudo-Apulejusz 191). 
153v.38)27, nie odnotował partii na temat Izydy i Ozyrysa28. Podobnie też czynił później w pracy translatorskiej, gdy luźno traktował swoją literacką podstawę do przekładu bajek i „zamiast bogów lub zamiast Jowisza, Izydy itd. mówi stale o Bogu" (Brückner 174). Raz natomiast wymienił imię Jowisza (A, 4v), gdy podkreślił cytat odnoszący się do nieba (celum): „per celum Iuppiter omnibus prebet vitam” (Ed. Rom., 153r.30-31)29, lecz tuż potem ominął opis bóstwa zwanego „pantomorphos" (,wszechkształtnym ${ }^{30}$ ) oraz opis sferycznych władców - „principes" (Ed. Rom., 153r. 32-38) $)^{31}$.

Przyglądając się tej selekcji, możemy zauważyć, że Biernat z Lublina nie trzymał się florenckiej koncepcji filozofii, która swobodnie łączyła elementy prisca theologia, wątki pogańskie, mistyczne, kabalistyczne i chrześcijańskie. Biernat z Lublina dystansował się od renesansowych tendencji, w których odzywał się synkretyzm filozoficzno-religijny. Wybrał on z nauki Hermesa Trismegistosa jedynie cytaty odnoszące się do Boga jednego (unus Deus). Konsekwentnie pomijał politeistyczne treści na rzecz rozumienia monoteistycznego.

Wszystkie powtarzające się $\mathrm{w}$ tekstach hermetycznych określenia właściwe dla „boga drugiego" (deus secundus), czyli przebóstwionego uniwersum, takie jak: effector, gubernator, rector, administrator, distributor, tributor, dispensator, praestitor $\mathrm{w}$ wyborze sentencji dokonanym przez Biernata odnoszą się ostatecznie do jednego jedynego Boga, „ojca i pana wszechrzeczy" - „vel pater, vel dominus omnium” (Ed. Rom., 153v.12); (A, 4v) ${ }^{32}$ - „zasiadającego ponad szczytem najwyższych niebios", , poza niebem” - „desupra vertice summi celi consistens”, „ultra celum” (Ed. Rom., 155v.34-35); (A, 6r) 33 - który „istnieje sam w sobie i sam z siebie, i cały wokół siebie, pełny i doskonały" - „Solus enim deus et merito solus in se \& est et a se \& circum se totus est, plenus atque perfectus" (Ed. Rom., 157r.5-6); (A, 8v) ${ }^{34}$ - który , ,jest ponad wszystkim i wokół wszystkiego $35{ }^{\prime \prime}$ - „deus super omnia est et circa omnia" (Campanelli ed., 69,235); (A, 23r). Teologia hermetyczna - tak jak przeczytał i odnotował ją Biernat z Lublina - koncentruje się na Bogu, który jest zarazem

27 Por: Ascl. XXI (NF II, 322.8); (Pseudo-Apulejusz 196).

${ }^{28}$ Owych dicta nie uwzględniono już w Ed. Rom. Por: Ascl. XXXVII (NF II, 348.6-10); (Pseudo-Apulejusz 216).

29 Por: Ascl. XIX (NF II, 318.23-24). „Przez niebo bowiem Jowisz obdarza wszystko życiem” (Pseudo-Apulejusz 193).

${ }^{30}$ Pominął także opis nauki o zodiaku zwanego „omniformis” („wszechkształtnym”) z C. H. XIII.12 (Campanelli ed., 100.114-117).

31 Por: Ascl. XIX (NF II, 319.1-9).

32 Por: Ascl. XX (NF II, 320.11-12); (Pseudo-Apulejusz 194).

33 Por: Ascl. XXVII (NF II, 332.8-12); (Pseudo-Apulejusz 204).

${ }^{34}$ Na marginesie odnotował Biernat "dei perfectio". Por. też: Ascl. XXX (NF II, 338.17-19); (Pseudo-Apulejusz 208).

${ }^{35}$ C. H. X.22 (TS). 
i ,jednym i wszystkim” - „unus et omnia” (Ed. Rom., 153v,24); (A, 5r) ${ }^{36}$ - który jest "Monadą" czyli „jednością wszystkich pierwiastków, korzeniem i źródłem ${ }^{37 " ~-~}$ "Monas, idest unitas omnium principium, radix atque origo" (Campanelli ed., 34,89-90); (A, 16v).

Biernat z Lublina jako czytelnik pism hermetycznych kierował swą uwagę na filozoficzno-religijny monizm. Stawiał akcenty tam, gdzie odzywał się archetyp jednoczący, łączący i integrujący, natomiast wszelki ontologiczny pluralizm i religijny politeizm traktował $\mathrm{z}$ dużym dystansem. Stąd też wynika jego podkreślenie na karcie $24 \mathrm{v}$, dictum wybrane jako konkluzja całego wykładu na temat „Wielości": „,impossibile est duos aut plures esse factores; neque enim ordo unus probaretur in multis ${ }^{38}$. Na marginesie tego podkreślenia odnotował Biernat „unitas dei".

Na podstawie powyższych wyborów można wywnioskować, że owo sformułowanie „jedność Boga" (unitas dei) stanowiło dla Biernata z Lublina myśl przewodnią $\mathrm{w}$ hermetycznej teologii. Stąd też kolejne podkreślenie na tej samej karcie: "Nam anima una, vita una, unaque materia" (Campanelli ed., 75.110-111) ${ }^{39}$. Bóg objawia się (Deus patens) jako jedność (unitas), całość (totus) i pełnia (plenus), łącząc w sobie sprzeczności, materialne zróżnicowanie, zjawiskowe wielokrotności, gatunkową różnorodność. Hymn na cześć Jego stwórczych mocy Biernat przepisał w całości ${ }^{40}$. Odnotujmy tutaj dicta i podkreślenia Biernata z karty $10 \mathrm{r}$ antologii ${ }^{11}$ :

Hic ergo mundus qui dicitur sensibilis receptaculum omnium sensibilium specierum qualitatum vel corporum, que omnia sine $\mathrm{deo}^{42}$ vegetari non possunt. Omnia enim

36 Biernat z Lublina przepisał to dictum z literówką „sit unque et omnia”, co poprawił na marginesie glosą „unus et omnia”. Por: Ascl. XX (NF II, 321.6-7); (Pseudo-Apulejusz 195).

${ }^{37}$ C. H. IV.10 (TS).

38 Patrz: C. H. XI.9. „Niemożliwym jest, aby było dwóch stwórców albo i więcej, w wielości bowiem traci na znaczeniu jednolite uporządkowanie" (TS). Współczesne wydanie krytyczne różni się od edycji, z której korzystał Biernat z Lublina. Czytamy tam: „neque enim ordo unus servaretur in multis” (Camapnelli ed., 74.93-94). „W wielości bowiem nie zostaje zachowane jednolite uporządkowanie" (TS).

39 Patrz: C. H. XI.11. „Albowiem jedna dusza, jedno życie i jedna jest materia” (TS).

40 Patrz: C. H. XIII.17-20. Biernat z Lublina przepisał ten fragment na kartach 29r-v (Campanelli ed., 103-104.2-32).

${ }^{41}$ Patrz też: Ed. Rom., 158r.18-25. Por: Ascl XXXIV (NF II, 344.19-27-345.1-2). „Świat zaś, który określany jest jako podległy zmysłom, jest zbiornikiem jakości i ciał wszelkich istot postrzegalnych zmysłami, które wszystkie bez boga nie moga żyć. Bóg bowiem jest wszystkim, od niego wszystko pochodzi i od jego woli zależy. Ta całość jest dobra, piękna i mądra, niezmienna i tylko sama zdolna do odczuwania i poznawania samej siebie; bez niej niczego nie było, nie ma i nie będzie. Wszystko bowiem jest z niej, w niej i przez nią - różne i wielorakie w swych kształtach jakości, wielkie ilości, a także wielkości przekraczające wszystkie miary oraz formy o wszelakich kształtach" (Pseudo-Apulejusz 213).

42 Manuskrypt Biernata z Lublina wyjątkowo różni się w tym miejscu od Editione Romana, gdzie zamiast „sine deo" czytamy "sine dubio". Edycja rzymska podąża w tym miejscu za rękopisem 
deus et ab eo omnia et eius voluntatis omnia, quod totum est bonum, decens, immutabile et prudens et ipsi soli sensibile et intelligibile et sine hoc nec fuit aliquid, nec est, nec erit; omnia enim ab eo et in ipso et per ipsum; et multiformes qualitates et magnae quantitates et omnem mensuram excendentes magnitudines et omniformes species.

„Wola Boga” (voluntas Dei) stanowiła dla Biernata spoiwo dla zróżnicowanych tematycznie partii Asclepiusa, wówczas - przypomnijmy - tytułowanego De divina voluntate („O woli boskiej”).

Obraz Boga, jaki wyłania się z sugestywnie wybranych przez Biernata sentencji hermetycznych, naprowadza na przeżycie mistyczne, które jest wiedzą (cognitio) o jednym Bogu (Deus unus, Deus unicus), rozpoznaniem Jedni (monas, unitas) oraz doświadczeniem jednej pełnej wszechogarniającej boskości (divinitas). Bóg, który się objawia jako jedność różnorodnych elementów, jest "ponad-przewyższającym dobrem 43 ” - „insuperablile bonum” (Camapnelli ed. 33, 74); (A, 16v) - zarazem jest „niewyrażalny44” - „ineffabilis” (Campanelli ed., 19.267); (A, 13v) - „nieskończony, niepojęty i niepodlegający ocenie ${ }^{45^{\prime}}$ - „infinitum, incomprehensibile, inestimabile est” (Ed. Rom., 157r.18-19); (A, 8v) - za materialnymi „widmami46” - „idola” (Camapnelli ed., 45.65-67); (A, 19r) - zawsze ukryty (Deus latens).

Dei nominatio. Pozytywny i afirmatywny stosunek do rzeczywistości prowadzi do kontemplacji Boga w każdym przejawiającym się zjawisku, wówczas Bóg jako jedność wszystkiego posiada każde imię (omninominis) - Bóg, który się objawia (Deus patens). Lecz ludzkie uwarunkowanie w fizykalnym stworzonym świecie nie pozwala Go określić i zdefiniować, więc umysł (a raczej „oczy umysłu” - „mentis oculi47”) wyklucza wszelkie widmowe zjawiska, wszelką zmysłową percepcję i usiłuje nazwać Boga drogą negacji - via negationis (Jonas 305). Wówczas Bóg nie posiada żadnego imienia (innominis) - Bóg, który się skrywa (Deus latens). Obie metody teologicznej eksplikacji - afirmację i negację - konsekwentnie stosowano we wszystkich pismach hermetycznych jako metodę kontemplacji Boga. Obie drogi do boskiego poznania zachował też $w$ swojej antologii Biernat z Lublina. Na początku wypisów z V rozdziału Corpus hermeticum odnotował na karcie 39v zdanie: „DEUS LATENS SIMUL ET PATENS EST” (Campanelli ed.,

\footnotetext{
z Paryża (Paris, Bibliothèque nationale de France, lat. 6672, sec. XV, karta 127v.). Jednakże większość manuskryptów odnotowuje w tym miejscu "sine deo". Zatem Biernat z Lublina znał również inne redakcje tekstu oprócz drukowanej edycji z Rzymu.

${ }^{43}$ C. H. IV.8 (TS).

${ }^{44}$ C. H. I.31 (TS).

45 Por: Ascl. XXXI (NF II, 339.23-24), gdzie czytamy: „indefinitum, inconprehensibile, inaestimabile est" - „nieokreślone, niepojęte i niepodlegające ocenie” (Pseudo-Apulejusz 209).

${ }^{46}$ C. H. VI.4 (TS).

${ }^{47}$ Podkreślenie na karcie 17r. Patrz: C. H. V.2 (Campanelli ed., 38.23). Patrz także: sentencja przepisana na karcie 29r „Hic mentis est oculus” z C. H. XIII.17 (Campanelli ed., 113.11).
} 
37.2) 48. Jednakże więcej uwagi przeznaczył Biernat na te fragmenty, które drogą negacji wyrażają boską „nierozstrzygalność” i „niewyrażalność”. Warto przyjrzeć się tym dicta bardziej szczegółowo.

Na karcie 19v podkreślił sentencję: „Is nec auribus percipitur, nec cernitur oculis, nec sermone profertur. Sola mens eum prospicit, sola mens praedicat" (Campanelli ed., 47.14-16) ${ }^{49}$. Podkreślił też dicta na temat mistycznej ciszy z C. H. I.31: „Ineffabilis, solo silentio praedicandus" (Campanelli ed., 19.267); (A, 13v) ${ }^{50}$ oraz z C. H. X.5-651:

Tunc autem poterimus mentis oculos elevare: bonumque decorem incomprehensibilemque prospicere, cum nihil de illo prorsus dixerimus. Eius cognitio divinum silentium est et intenta sensuum omnium applicatio ${ }^{52}$, qui id intelligit, nihil potest aliud cogitare $(\mathrm{A}, 21 \mathrm{v})^{53}$.

Zgodnie z teologią negatywną, Bóg nie posiada żadnej nazwy, lecz zarazem $\mathrm{w}$ teologii pozytywnej odpowiada Mu absolutnie wszelka nazwa. Połączenie tych dwóch sposobów opisu reprezentuje w pismach hermetycznych poetyka sprzeczności i paradoksu. Oto sentencje i podkreślenie w rękopisie Biernata na temat Dei nominatio z C. H. V.10:

Hic deus nomine melior; hic occultus, hic rursus omnium patentissimus; hic menti conspicuus, hic presens oculi; hic incorporeus hic (ut ita dixerim) multicorporeus. Nam nihil in corporibus est quod ipse non sit; omnia enim ipse solus existit. Nomina insuper habet omnia, quoniam unius est pater. Nomen quoque nullum habet, quoniam pater est omnium (Campanelli ed. 41.95-101); (A, 18r)54.

Analogiczne sentencje znajdujemy w XX rozdziale Asclepiusa - przywoływane wielokrotnie $\mathrm{w}$ recepcji średniowiecznej - gdzie Hermes Trismegistos naucza

48 "Bóg jest ukryty, a zarazem objawiony” (TS).

${ }^{49}$ Patrz: C. H. VII.2. „Ani słuch go nie dosłyszy, ani wzrok nie spostrzeże, ani mowa nie wymówi. Jedynie umysł w Niego wnika, jedynie umysł Go wyjawia" (TS).

50 „Niewyrażalny, jedynie w ciszy wypowiadalny" (TS).

51 Por: Campanelli ed., 61.49-54. Tutaj na początku owego dictum czytamy: „tunc autem poterimus mentis oculos elevare bonique decorem incorruptibilem incomprehensibilemque prospicere".

52 Warto zwrócić uwagę, że Marsilio Ficino tłumaczy w tym miejscu grecki termin katapүia jako applicatio (pol. „przyłączenie”), gdy tymczasem słowo to oznacza „stłumienie, zniesienie, likwidację".

53 „Natomiast dopiero wtedy będziemy mogli wznieść oczy umysłu i ujrzeć dobro oraz nieuchwytne piękno, kiedy nic zupełnie o Nim nie powiemy. Wiedza o Nim jest boską ciszą i intensywnym złạczeniem wszystkich zmysłów. Ten, który to zrozumiał, nie jest w stanie wiedzieć już o niczym innym" (TS).

54 „Oto Bóg doskonalszy ponad każde imię, oto Ów ukryty, lecz i nade wszystko objawiony; oto Ów w umyśle widzialny, lecz i przed oczami dostrzegalny, oto bezcielesny i oto (że tak powiem) wszechcielesny; nie ma bowiem ciała, którym by nie był gdyż we wszystkim On istnieje. Nadto, każde imię posiada, gdyż jest On ojcem jedności. Jak również żadnego imienia nie posiada, gdyż jest On ojcem wszystkiego" (TS). 
o Bogu „o jednym imieniu, lub raczej o każdym imieniu” - „Hunc vero uno nomine, vel potius omni nomine" (Ed. Rom., 153v.23); (A, 5r) ${ }^{55}$.

Fakt, że Biernat z Lublina tak uwydatniał sentencje teologii negatywnej, świadczy o tym, że podstawy humanistycznych wartości nie kształtował on jedynie $\mathrm{w}$ ramach profanum, czyli - jak to przedstawiano latach pięćdziesiątych XX wieku - jako tak zwany "pisarz postępowy" oraz "świadomy i walczący ideolog" (Budzyk 95), który w walce $z$ "feudalnym ustrojem” i „reakcyjną ideologią kościoła” upominał się o "konieczność stworzenia nowych świeckich norm etycznych" (Ziomek XCV-XCVI, XLIX). Widać po jego praktyce czytelniczej, że przywiązywał Biernat szczególną wagę do treści o charakterze stricte mistycznych, zgodnych z koncepcją "uczonej niewiedzy" (docta ignorantia) ${ }^{56}$. Dlaczego nie wyraził tego bezpośrednio w swojej twórczości artystycznej, być może wyjaśnia jego aforyzm „Tacyś są, co sie gadają,/ Tajemnic Boskich badają:/ Sami sobie rozum każą,/ Iż więc potym bez wstydu łżą̧7". Na tę samą treść zwraca uwagę dictum Hermetis z XXXII rozdziału Asclepiusa, którego Biernat najpierw się nie dopatrzył lub pominął, lecz po kilku kolejnych zdaniach do niego powrócił, aby je uwypuklić podkreśleniem i glosą „tacenda divina mysteria” („,boskie misterium należne jest tylko w milczeniu"), dictum przepisane na karcie 9r: „Et vos o Cati et Asclepi \& Ammon intra secreta pectoris divina mysteria silentio tacete et taciturnitate servate" (Ed. Rom., 157v. 12-15) 58 .

Homo effector est deorum. Precyzyjne wybory Biernata wskazują na to, że znał on dobrze zróżnicowaną recepcję hermetyzmu i że świadomie wpisywał się w określony nurt myślenia o nauce Hermesa Trismegistosa. Jak zdążyliśmy zauważyć, sceptycznie traktował on synkretyczne poglądy florenckich filozofów. Nie podążał również za kierunkiem wyznaczonym przez średniowiecznych nauczycieli z Chartres, choć możemy zakładać, że znał ich teksty. Z pewnością podzielał mistyczne i filozoficzne poglądy teologii negatywnej propagowanej w XV wieku głównie przez Mikołaja z Kuzy. Jednakże głównym autorytetem, który wpłynął na

${ }^{55}$ Edycja NF II podąża za innymi manuskryptami niż Ed. Rom. i odnotowuje to zdanie w wersji: „hunc vero innominem vel potius omninominem” Patrz: Ascl. XX (NF II, 321.5-6). „raczej należałoby go uznać za bezimiennego, czy może jeszcze lepiej - za wszechimiennego" (Pseudo-Apulejusz 195).

${ }_{56}$ Mikołaj z Kuzy wyraźnie odnosił się do nauki Hermesa Trismegistosa. Jego docta ignorantia miała oparcie także w hermetycznych wykładach o bezimienności i nieokreśloności najwyższego Boga (Mikołaj z Kuzy 78).

57 Patrz: tekst nr 181, wers 13-16 (Biernat z Lublina 1997: 301).

58 "A wy, Tacie, Asklepiuszu i Ammonie, w ciszy swego serca milczcie o sekretnych boskich misteriach i w milczeniu je zachowajcie" (TS). Cytowane dictum z Ed. Rom. różni się od edycji NF II (Ascl. XXXII: NF II, 341.21-23). W wydaniu krytycznym czytamy bowiem: „et vos, o Tat at Asclepi et Hammon, intra secreta pectoris diuina mysteria silentio tegite et taciturnitate celate". Współczesne polskie tłumaczenie bazuje na edycji NF II: „Wy zaś, Thacie, Asklepiuszu i Ammonie, ukryjcie w zakamarkach swych serc święte tajemnice i nie wyjawiajcie ich nikomu" (Pseudo-Apulejusz 210-211). 
Biernatową recepcję pism hermetycznych, był św. Augustyn, który bardzo silnie ukształtował myślenie o nauce Hermesa Trismegistosa już wśród filozofów średniowiecznych.

Akcentowane $\mathrm{w}$ antologii Biernata hermetyczne treści o Bogu Jednym (Deus unus) wynikały w znacznej mierze z recepcji św. Augustyna. Autor De civitate Dei postrzegał mądrość i prawdziwość nauki Hermesa właśnie w nieustannym objawianiu "jednego prawdziwego Boga, sprawcy świata" (św. Augustyn 1998: 317-318). Zarazem naznaczył on pisma hermetyczne swego rodzaju cenzurą, która wywarła istotny wpływ na ich późniejszą recepcję. Jak wiemy, cenzura ta - czyli odpowiednia selekcja hermetycznych treści oraz ich sugestywna interpretacja dotyczyła tych fragmentów z Asclepiusa, które mówią o człowieku jako "twórcy bogów" („homo effector est deorum ${ }^{59 \prime)}$; konkretnie chodzi o dicta Hermetis z rozdziałów XXIII, XXIV, XXXVII, XXXVIII. Fragmenty te często wzbudzały kontrowersje i różnie się do nich odnoszono. Krytyka tego hermetycznego wykładu zawsze bazowała na interpretacji św. Augustyna.

Biernat z Lublina również popierał tę krytykę i także kierował się wyjaśnieniami św. Augustyna. Pominął on bowiem niemal zupełnie dicta z rozdziałów XXIII i XXIV Asclepiusa. Z rozdziału XXXVIII zachował tylko jedną sentencję, lecz nie przepisał jej w całości. Przyjrzyjmy się tutaj uważniej; czytamy w Editione Romana: „dii celestes inhabitant summa celestia, unusquisque per ordinem, quem accepit, conplens atque custodiens" (Ed. Rom., 159v.13-14) ${ }^{60}$. Biernat nie uwzględnił tutaj $(\mathrm{A}, 10 \mathrm{v})$ pierwszego słowa - „bogowie" (dii) - i rozpoczął zdanie od "celestes”, czym nadał sentencji inne znaczenie: „Niebianie zamieszkują najwyższe sfery niebios, wypełniając i strzegąc porządku, jaki każdemu z nich powierzono" (TS). Na karcie 10r odczytujemy natomiast dicta, które już w Editione Romana uległy wpływom św. Augustyna ${ }^{61}$ :

${ }^{59}$ Ed. Rom. podaje „homo effector est deorum” (Ed. Rom., 154v.11-12), natomiast edycja NF II podaje "homo fictor est deorum". Por: Ascl. XXIII (NF II, 325.8). W rozdziale Ascl. XXXVIII ponownie pojawiają się owe dicta. Edycja NF II redaguje w tym miejscu "sic homo fictor est deorum", nie odsyła jednak do Ed. Rom., gdzie czytamy „sic deorum actor est homo (Ed. Rom., 159r.11).

${ }^{60} \mathrm{NF}$ II odnotowuje natomiast "dii caelestes inhabitant summa caelestia, unusquisque ordinem, quem accepit, conplens atque custodiens" - Por: Ascl. XXXVIII (NF II, 349.9-11) - co Kazimierz Pawłowski tłumaczy: „Bogowie niebiańscy zamieszkują najwyższe sfery niebios i każdy z nich wypełnia i strzeże porządku powierzonego jego pieczy" (Pseudo-Apulejusz 216-217).

${ }^{61}$ Por: Ascl. XXXVII (NF II, 347.8-19). "Ze wszystkich niezwykłych rzeczy największy podziw wzbudza to, że człowiek był zdolny wynaleźć i stworzyć boską naturę. Nasi przodkowie wiele błądzili w kwestii bogów. Nie mając wiary i nie bacząc na cześć i świętość boską, wynaleźli sztukę, za pomocą której sprawili sobie bogów. Ze swoim wynalazkiem złączyli moc, która tkwi w naturze materii. A że nie mogli stworzyć dusz, przyzwali dusze demonów czy aniołów i wprowadzili je do posągów bogów i do świętych misteriów, by te idole posiadły moc czynienia zarówno dobrze, jak źle" (Pseudo-Apulejusz 215). 
Omnium mirabilium vincit admirationem, quod homo [divinam ${ }^{62}$ ] potuit invenire naturam eamque efficere, quoniam ergo proavi nostri multum errabant contra rationem deorum increduli \& non animadvertentes ad cultum religionemque divinam, invenerunt artem qua deos efficerent. Cui invente adiunxerunt virtutem de mundi natura convenientem eamque miscentes et quoniam animas facere non poterant, evocantes animas demonum vel angelorum eas indiderunt imaginibus suis divinisque mysteriis, per quas sola idola \& benefaciendi \& malefaciendi vires habere potuissent (Ed. Rom., 158v.21-29).

Powyższy passus według św. Augustyna przedstawiał przyczyny powstania idolatrii, czyli „liczne błędy przodków63” (św. Augustyn 1998: 319), którzy po czasach apokalipsy wołają o bogów i bogów kreują. Autor De civitate Dei wykorzystał te sentencje $\mathrm{w}$ swojej walce $\mathrm{z}$ pogańskim politeizmem oraz dla pouczeń $\mathrm{w}$ ramach etyki chrześcijańskiej. Zarazem okazywał ambiwalentny stosunek do Hermesa Trismegistosa. Nazywał go bowiem „mądrym mężem” (vir sapiens), który jednocześnie błądzi między siłami boskimi i diabelskimi (św. Augustyn 1998: 319).

Decyzja Biernata, aby $\mathrm{w}$ antologii zachować powyższy passus $\mathrm{z}$ Asclepiusa XXXVII, lecz odrzucić korespondujące z nimi fragmenty z rozdziałów XXIII, XXIV i XXXVIII bazowała z pewnością na wyjaśnieniu św. Augustyna, który uwydatnił przyczyny powstania owej „haniebnej sztuki” (św. Augustyn 1998: 319) - „ars detestanda". Autor antologii również kierował się etyką skoncentrowaną wokół jednego Boga. W związku z tym pomijał kwestię wielobóstwa, a dicta Hermetis, dotyczące kreowania bogów przez człowieka, z pewnością uznał za bałwochwalstwo. Jego czytelnicze itinerarium przebiegało - jak zauważyliśmy - w sposób bardzo uważny i wybiórczy oraz - podobnie jak u św. Augustyna - w sposób ambiwalentny. Stąd możemy także wnioskować, że Biernatowa recepcja pism Hermesa Trismegistosa wpisywała się w chrześcijański nurt hermetyzmu, dla którego praktyki magiczne, politeizm i idolatria były sprawą kontrowersyjną i kłopotliwą (Moreschini 51).

Na podstawie tego, co do tej pory powiedzieliśmy, jasnym się zdaje, że wskazówki, jak czytać pisma hermetyczne i które dicta Hermetis wybierać, mógł Biernat zaczerpnąć przede wszystkim od św. Augustyna lub od któregoś z filozofów kontynuujących jego myśl64. Idea jednego Boga według św. Augustyna wymierzona

${ }^{62}$ Editio Romana, a za nią Biernat, pomija w tym miejscu słowo „divinam” („boską”). Por: NF II, 347.9 .

${ }^{63}$ W De civitate Dei. Czytamy: "quoniam ergo proavi nostri multum errabant” (VIII, 24). Reinterpretacje przyczynowego „quoniam" przeprowadził Walter Scott (Scott 1985a: 359); (Scott1985c: 220); (Scott 1985d: 183).

${ }^{64}$ Najprawdopodobniej był to Hugo od św. Wiktora, którego pisma znajdowały się w licznych manuskryptach w Krakowie lub Tomasz Bradwardine, którego księgi De causa Dei wypełniają manuskrypt Biblioteki Jagielońskiej nr 653 III i w którym na marginesach zaznaczono glosą "Hermes” każ- 
była w wielobóstwo pogan i temu też - między innymi - miało służyć poznawanie starożytnej nauki. Biernat z Lublina w swojej twórczości literackiej nie traktował Hermesa Trismegistosa jako autorytetu. Nie manifestował postawy wtajemniczonego hermetysty, lecz - co zdążyliśmy już zauważyć - studiował pisma hermetyczne niezwykle skrupulatnie. Wnikał on w tę starożytną naukę nie jako wieszczący mag, ale jako pisarz (a nawet - powiedzielibyśmy - pedantyczny filolog) i chrześcijański humanista, który szukał wiedzy na temat „Boga jednego" (Deus unus). W tym celu traktował on Asclepiusa i Corpus hermeticum jako obszerny zbiór niezwykle trafnych i bogatych treściowo sentencji. W tym też punkcie znajdował Biernat konsensus między hermetyzmem i chrześcijaństwem.

Contemplatio dei. Poprzez wyżej omówione fragmenty pism hermetycznych Biernat z Lublina ukazuje się nam jako chrześcijański mistyk, który w dialogu $\mathrm{z}$ antyczną filozofią przyznaje pierwszeństwo umiejętności kontemplowania jednego Boga (Deus unus). Na marginesie karty 25v odnotował "contemplatio dei" przy takich oto sentencjach:

Nisi te deo aequaveris, deum numquam intelliges; nam simile semper a simili suo cognoscitur. Extende te ipsum in magnitudinem sine termino, emerge ex corpore, totum supergredere tempus, eternitas esto: sic deum denique noveris (Campanelli ed., $80.203-207)^{65}$.

Wiadomo nie od dziś, że takie stwierdzenia wyrwane z całości wypowiedzi lub cytowane bez znajomości kontekstu, tradycji i nawiązań międzytekstowych uwalniają hybris człowieka i pobudzają do czynów tragicznych w skutkach. Zwróćmy jednak uwagę, że hermetyczne rozważania o boskości (sermo divinus) akcentował Biernat wraz z etycznymi zadaniami człowieka. Zadania te według dicta Hermetis polegają na integracji hierarchicznego porządku duchowo-materialnego. Bóg, świat i człowiek działają w nieustannej relacji ze sobą, co podkreślił autor antologii między innymi na karcie $15 \mathrm{v}^{66}$ :

Demisit itaque hominem, immortalis animantis mortale animal, et mundus quidem refertus est animalibus viventis mundi per intellectum atque rationem. Homo enim effectus est divini operis contemplator, quod profecto dum admiraretur, auctorem eius agnovit (Campanelli ed., 31.11-16).

dy cytat z pism hermetycznych. Na autorytet św. Augustyna powoływali się również - przypomnijmy - współczesny Biernatowi Jakuba Lefèvre d'Etaplesa oraz Marsilio Ficino.

${ }^{65}$ C. H. XI.20. „Jeśli nie będziesz na równi z Bogiem, nigdy Boga nie pojmiesz albowiem podobne poznaje jedynie przez sobie podobne. Rozciągnij samego siebie do wielkości bezgranicznej, wyjdź poza ciało, przekrocz wszelki czas, stań się wiecznością, a osiągniesz poznanie Boga" (TS).

${ }^{66}$ C. H. IV.2. „Posłał zatem człowieka - stworzenie śmiertelne, ożywione nieśmiertelnością. Żywe stworzenia - w obmyślonym uporządkowaniu - przepełniły świat, lecz to człowiek został ukształtowany, by kontemplować dzieło boskie, gdyż zaprawde, podziwiajac je, poznaje jego stwórce" (TS). 
Podkreślenia w tych miejscach wskazują, że Biernat akcentował w hermetyzmie etykę, zgodnie z którą człowiek poznaje zróżnicowany i stworzony świat, aby powracać do wiedzy o jednoczącym Stwórcy. Kontemplować Boga to poznawać rzeczywistość na sposób boski (sensus divinus), czyli współistnieć z jednym, tożsamym ${ }^{67}$, niepodzielnym, nieśmiertelnym, nieokreślonym, bezcielesnym, dobrym Stwórcą ${ }^{68}$. Warto tutaj również przypomnieć podkreślenie Biernata na karcie antologii 21r (dicta z C. H. IX.10), gdzie zaakcentował sentencję Hermesa Trismegistosa, iż „Rozumieć znaczy wierzyć. Nie wierzyć zaś - rzecz jasna - znaczy nie wiedzieć" (TS) - „Intelligere enim ipsum credere est, at non credere proculdubio ignorare" (Campanelli ed., 57.102-103). Oczywiście chodzi tu o wiedzę, która jako boskie natchnienie oraz jako dar boski (synonimicznie: dei donum, numen divinum, munus dei) jest wiedzą ponadzmysłową ${ }^{69}$, identyczną z wiarą. Natomiast wiedza wyuczona - według hermetyzmu ${ }^{70}$ - naukowa, kategoryzująca, zracjonalizowana i dyskursywna (èpistème - scientia; logós - ratio) jest właściwa dla myślenia w świecie (sensus mundanus). Poznawać na sposób światowy to współistnieć z różnicującym, podzielnym, śmiertelnym, określonym, cielesnym ${ }^{71}$ stworzeniem. Na kartach manuskryptu Biernata kontemplacja jednego Boga stanowi punkt wyjścia dla zrozumienia zróżnicowanego świata. Hermetyczna etyka prowadzi do rozpoznania relacji między jednością i wielością.

\section{Sensus mundanus}

Kosmos vel hyle. Pojęcie „świata” w pismach hermetycznych prowadziło do różnych interpretacji. Otóż łacińskie słowo mundus stanowi ekwiwalent dla dwóch greckich słów: kosmos oraz hyle. Hyle według hermetyzmu to bezforemna materia, kosmos to harmonijny ład. Te dwa sprzeczne ze sobą obrazy świata przewijają się przez rożne partie tekstów hermetycznych. Przyjrzyjmy się, ku której interpretacji skłaniał się

${ }^{67} \mathrm{Na}$ karcie 8v antologii czytamy: „Deus igitur stabilis fuit semperque est \& cum eo similiter eternitas” (Ed. Rom., 157v.10-11). Por: Ascl XXXI (NF II, 339.4-5). „Bóg więc był zawsze stały i podobnie do niego zawsze trwała wieczność" (Pseudo-Apulejusz 208).

68 Patrz: C. H. II.14-15 (Campanelli ed., 24-25.94-103); C. H. VI.4 (Campanelli ed., 45. 63-65).

${ }^{69}$ Patrz: C. H. IV.4-6 (Campanelli ed., 31-33.23-61); C. H. X.9-10 (Campanelli ed., 63.88-110) oraz Ascl. I (Ed. Rom., 148v.4). Por: NF II, 296.6-7. Interesującą interpretację porównawczą przedstawił Garth Fowden (Fowden 101-102).

${ }^{70}$ Patrz: Ascl. XI oraz Ascl. XIII.

${ }^{71} \mathrm{Na}$ karcie 2r Biernat przepisał: „Sunt ab omnibus cognationis divinae partibus aliena omnia, quaecumque terrena corporali cupiditate possidentur" (Ed. Rom., 151r.31-33). Por: Ascl. XI (NF II, 309.9-11). „Wszystkie rzeczy ziemskie, które posiadł człowiek na zasadzie cielesnej pożądliwości, są całkowicie obce tym częściom istoty ludzkiej, którymi jest ona pokrewna bogom" (Pseudo-Apulejusz 184). Ciało jako tunikę, mroczne okrycie, grób, żywą śmierć opisuje C. H. VII (Campanelli ed., 47-48.1-29) oraz C. H. X.18 (Campanelli ed., 66-67.178-191). 
Biernat $\mathrm{z}$ Lublina. Jak $\mathrm{w}$ antologii Biernata $\mathrm{z}$ Lublina przedstawia się recepcja hermetycznych wypowiedzi na temat świata? W tym celu porównajmy wybrane dicta Hermetis, które korespondują ze sobą na sposób analogiczny lub też polemiczny.

Wiemy, na podstawie wcześniej wskazanych już uwag, że polski filozof nie odnotował passusów z rozdziału VIII Asclepiusa, które mówią o świecie jako „drugim bogu" (deus secundus). Kontynuacja tego wywodu znajduje się w IX traktacie Corpus hermeticum ${ }^{72}$. Tego tekstu Biernat $\mathrm{z}$ Lublina również nie przepisał w całości. Przeprowadził bardzo uważną selekcję. Dicta Hermetis z fragmentu C. H. IX.8 w przekładzie Marsilia Ficina wyraźnie wskazują tutaj na greckie słowo kosmos.

Deus igitur cosmi (id est mundi) pater, cosmus autem eorum que in cosmo, et cosmus quidem dei filius, que vero in cosmo sub cosmi ditione consistunt. Ac iure cosmus appelatus es: omnia siquidem varietate generationis kosmêi (idest exornat) nec non indesinentia vite, operatione perpetua, necessitatis celeritate, elementorum commixtione, ordine genitorum. Ipse ergo cosmus (id est ornatus) necessitate simul et merito nominatus est (Campanelli ed., 56.86-93) ${ }^{73}$.

Biernat z Lublina nie zachował powyższego wyjaśnienia dla słowa kosmos mundus, "syna boga". Zachował natomiast dwie adnotacje translatologiczne anonimowego tłumacza Asclepiusa, mówiące o świecie jako hyle - „bezforemnej materii" - na karcie 3v "hyle, quem grece credimus mundum” (Ed. Rom., 152r.18-19) ${ }^{74}$ oraz na karcie 4r "hyle autem vel mundus” (Ed. Rom., 152v.24)75.

Mundus bonus vel malus. Porównajmy teraz passusy, które wychwalają piękno i dobro kosmosu, oraz te, które uznają świat za "ogrom zła”. Możemy zauważyć, że Biernat nie przepisał całego rozdziału XXXVI Ascelpiusa, gdzie w afirmatywny sposób Trismegistos przedstawia zmienny, zróżnicowany, płodny świat. Uwagę zwraca także selekcja zdań z Ascl. XXIX; otóż rozdział ten autor antologii odpisał na karcie 7r-v, a jedyne dicta, których tutaj nie uwzględnił, odnoszą się do nieśmiertelności uniwersum, świata „wiecznie żywego" - „animal mundus vivens semper" (Ed Rom., 156v.17-21) ${ }^{76}$. Nie przepisał także początku rozdziału XXV,

72 Por. uwagi i adnotacje Waltera Scotta (Scott 1985a: 77); (Scott 1985b: 203). Warto też zauważyć, że świat jako „bóg” jest motywem charakterystycznym dla kosmologii stoickiej, a świat jako „drugi bóg" to również motyw platoński (Jonas 257-261).

73 „Bóg jest ojcem kosmosu, czyli świata. Kosmos natomiast tego, co się w nim zawiera. Kosmos jest zaprawdę synem boga, natomiast to, co zawiera się w kosmosie, kosmosowi podlega. Słuszne jest zatem określenie <kosmos $>$, jeśli stanowi on ozdobę dla wszelkiego powstającego zróżnicowania. Jeśli nieustannie trwa przy życiu, w ciągłym działaniu, w pędzącej konieczności, w jedności żywiołów, w uporządkowanym cyklu powstawania, to nie inaczej trzeba go nazywać, jak tylko kosmosem" (TS).

74 Por: Ascl. XIV (NF II, 313.4-5). „hyle, bo tak z grecka przywykliśmy nazywać świat” (PseudoApulejusz 188).

75 Por: Ascl. XVII (NF II, 315.24-25). „hyle natomiast, czyli świat” (Pseudo-Apulejusz 190).

76 Por: Ascl. XXIX (NF II, 337.5-11); (Pseudo-Apulejusz 207). 
w którym eschatologiczna wizja upadku zostaje zderzona z harmonijnym obrazem kosmicznej budowli. Przypomnijmy:

hoc totum bonum, quo melius nec est nec fuit nec erit, quod videri possit, periclitabitur eritque tedium omnibus ac per hoc contemnetur nec diligetur totus hic mundus, dei opus immutabile, gloriosa constructio, bonum multiformi imaginum varietate conpositum, machina voluntatis dei in suo opere sine invidia suffragantis, omnium in unum, quae venerari laudari amari denique a videntibus possunt, multiformis adunata congestio (Ed. Rom., 155r.22-29) ${ }^{77}$.

Biernat z Lublina zdecydował się natomiast na te frazy, które opisują kosmiczny mundus jako twór boski powstały z woli Boga i od Jego woli całkowicie uzależniony. Deus omnia - jak to odnotował Biernat na marginesie wyżej już cytowanej karty 10r78, gdy przepisywał fragment XXXIV rozdziału Asclepiusa. Przypomnijmy analogiczną sentencję z XXIX rozdziału:

Sol enim sicut mundus sempiternus est, sic et ipse semper gubernator vitalium vel totius vivacitatis eorumque frequentator \& dispensator est. Deus ergo viventium vel vitalium, quae sunt in mundo sempiternus gubernator est. Ipse dispensator eternus; semel autem dispensauit eterna lege; cunctis uitalibus uitam praestans. Hoc more, quo dicam (Ed. Rom., 156v.22-26; A, 7v) ${ }^{79}$.

Zamierzenie to, czyli kolejny rozdział (Ascl. XXX), mówi o świecie jako niejednostajnym i zróżnicowanym uniwersum. Biernat przepisał go w całości. Wydobył w ten sposób kontrast między kosmiczną zmiennością a boską stabilną doskonałością. Podkreślił sentencję "Cunctis ergo ita se habentibus nihil stabile, nihil fixum, nihil inmobile nec nascentium nec caelestium nec terrenorum: solus enim deus"

77 Różnice redakcyjne pomiędzy Ed. Rom.] NF II: nec est nec fuit] nec fuit nec est; tedium omnibus] grave hominibus; immutabile] inimitabile; sine] absque; omnium in unum] in unum omnium. Por: Ascl. XXV (NF II, 328.17-24-329.1). „Tak oto ten dobry wszechświat, od którego nigdy ani nie było, ani nie ma, ani nigdy już nie będzie nic lepszego, co mogłyby oglądać oczy ludzkie, znajdzie się w niebezpieczeństwie i stanie się ciężarem dla ludzi [Ed. Rom. „odrażający dla wszystkich”]. Przez to znajdzie się w pogardzie i bynajmniej nie będzie uwielbiany cały ten świat - to niepowtarzalne [Ed. Rom. „niezmienne"] dzieło boga, pełna chwały budowla; dobro złożone z wielorakiej rozmaitości obrazów; machina woli boga, który nie odmawia pomocy swemu dziełu; doskonałe złożenie, w którym zostało doprowadzone do jedności, przy całej swej wielorakości, to wszystko, co może być czczone, wielbione i wreszcie kochane przez tych, którzy je oglądają" (Pseudo-Apulejusz 201). W nawiasie kwadratowym wskazuję istotne zmiany znaczeniowe, które powstają w przekładzie na podstawie edycji Ed. Rom.

78 Patrz: przypis nr 41.

79 Por: Ascl. XXIX (NF II, 337.12-18). „Tak samo jak świat jest wieczny, tak też i słońce jest zawsze władcą stworzeń ożywionych i stale udziela im siły życiowej. Bóg jest więc odwiecznym władcą wszystkich istniejących w świecie stworzeń żywych, czyli zdolnych do życia, a także wiecznym dawcą ich życia. Życie, raz przydzielone wszystkim stworzeniom zdolnym do życia, jest im zagwarantowane odwiecznym prawem w ten sposób, jak zamierzam to przedstawić" (Pseudo-Apulejusz 207). 
(Ed. Rom., 157r.3-4); (A, 8r) 80. W ten sposób zaznaczył, że atrybuty piękna i dobra zarezerwowane są tylko dla Boga, o czym najdobitniej mówi sam tytuł VI traktatu Corpus hermeticum: Quod in solo deo bonum est podkreślony w rękopisie Biernata na karcie 18v (Campanelli ed., 43.1) ${ }^{81}$. Oto wybór sentencjii podkreślenie na karcie 19r $\mathrm{z}$ tegoż traktatu:

Equidem ingentes deo gratias habeo, qui de natura boni cogitanti mihi sententiam hanc certam infundit, quod in mundo bonum esse non possit, siquidem mundus congeries est malorum, deus autem boni vel bonum dei exuberans plenitudo (Campanelli ed., $45.57-61)^{82}$.

Hermetyczne sentencje przepisane przez Biernata z Lublina do antologii mówią więcej o niedoskonałości świata, które przepełnia zło niż o harmonii świata, które przepełnia piękno i dobro (Ascl. XXV). Oto dicta Hermetis na karcie 19r:

Nam generatio passio quedam est; ubi autem passio, nullo modo bonum; ubi bonum, neque passio penitus ulla; ubi dies, nullo modo nox; ubi nox, neque etiam dies. Quapropter in generatione bonum esse non potest (Campanelli ed., 44.28-32) ${ }^{83}$.

$\mathrm{Z}$ drugiej strony, traktat C. H. IX stwierdza polemicznie - w konfrontacji z traktatem VI - iż zło (gr. kakia, łac. improbitas) zamieszkuje jedynie na obszarach ziemskich (terra provincia): "Ziemskich - powiadam - a nie, czemu niektórzy bezecnie wtórują, że chodzi o cały wszechświat" (TS) - "terram dico, non mundum totum, ut impii quidam oblocuntur" (Camapnelli ed., 54. 48-49). Biernat z Lublina jednakże nie uwzględnił tego zdania $\mathrm{w}$ antologii, mimo że znajduje się ono $\mathrm{w}$ samym środku przepisywanego wykładu na kracie 20v.

Porównując na kartach antologii dicta Hermetis z traktatu C. H. VI, gdzie odczytujemy pesymistyczny opis świata oraz z C. H. IX, gdzie znajdujemy optymistyczny obraz kosmosu, możemy zauważyć, że Biernat z Lublina silniej akcentował treści z traktatu VI. Wybierał on z tekstów hermetycznych te sentencje, które

80 Por: Ascl XXX (NF II, 338.15-1). „Skoro tak się rzeczy mają, to nie istnieje nic stałego, nic trwałego, nic niezmiennego ani wśród stworzeń zrodzonych, ani ziemskich, ani niebieskich. Jedynie - bóg" (Pseudo-Apulejusz 208).

81 „Dobro jest jedynie w bogu” (TS). Na różnice w pojmowaniu dobra i zła między C. H. II a C. H. VI wskazuje Walter Scott (Scott 1985a: 169-170). Patrz także: C. H. IV.8: „Insuperabile enim bonum est, sine termino, infinitum, quoad se numquam incipiens, quoad humanam cognitionem principium habens” (Campanelli ed., 34.74-76). „Dobro jest bowiem nieprzebyte, bezgranicznie nieskończone, nigdy nierozpoczęte, stanowi początek dla wiedzy człowieka" (TS).

82 C. H. VI.4. "Zaiste, niezmiernie jestem bogu wdzięczny za wiedzę o naturze dobra, że napełnił mnie tą niezbywalną myślą, albowiem niemożliwym jest, aby dobro w świecie zaistniało. W świecie panuje ogrom zła. Natomiast boga przepełnia dobro, lub też dobro jest przepełnione Bogiem" (TS).

${ }^{83}$ C. H. VI.2. "Cykl powstawania jest pewnym doznaniem. Nie sposób, by dobro było tam, gdzie i doznawanie. Tam, gdzie dobro, nie ma żadnego doznania. Nie sposób, by dzień widniał wraz z nocą. Tam, gdzie noc, nie ma dnia. Dlatego w cyklu powstawania dobro zaistnieć nie może" (TS). 
dobro, piękno i prawdę przyznawały jedynie najwyższemu Bogu. Przykładem jest także podkreślenie na karcie 9r: "cuius veritatis in mundo nequidem extrema linea umbra dinoscitur" (Ed. Rom., 157v. 9-10) ${ }^{84}$.

Sensus divinus vel sensus mundanus. Oczywiście błędem byłoby postrzeganie tych wyborów jako oznaki manicheizmu lub jakiegokolwiek gnostyckiego dualizmu. Biernat z Lublina wynotowywał również w swoim manuskrypcie dicta Hermetis, które mówiły o afirmacji kosmicznego ładu. Warto więc tutaj porównać kolejne fragmenty z Corpus hermeticum, tym razem dicta analogiczne: passus z traktatu V, którego Biernat nie odnotował oraz passus z traktatu XI, który zapisał na kartach 24r-v antologii ${ }^{85}$.

\section{Corpus hermeticum V.5:}

Utinam tibi daretur, o filii, facultas ut alarum adminiculo in sublimem aeris plagam volares mediamque inter celum ac terram regionem sortitus conspiceres terre quidem soliditatem, maris diffusionem, fluxum fluminum, aeris amplitudinem, ignis actam celeritatem, astrorum cursus, celi rapidam velocitatem. O felicissimum, filii, spectaculum, o beatissimam visionem, siquidem uno luminum motu seriem mundi totius comprehenderes, immobilemque factorem concitum, latentem quoque perspicuum cerneres (Campanelli ed., 39.49-57) ${ }^{86}$.

\section{Corpus hermeticum XI.787:}

[Inspice] preterea mundos septem suppositos, ornatu mirifico fabricatos ordine sempiterno [cursu suo differenter complentes evum], plena lumine singula, ignis vero in

84 Por. Ascl. XXXII (NF II. 341.15-16). „Nawet cienia tej prawdy, choćby w zarysach nie da się rozpoznać w świecie" (Pseudo-Apulejusz 210).

85 Te dwa passusy zestawia także Andre Jean Festugière (Festugière 1949: 55-57).

86 „Obyś otrzymał - synu - ową skrzydlatą zdolność, dzięki której wzlecisz w podniebne przestworza i jako wyniesiony $\mathrm{w}$ obszary między niebem a ziemią ujrzysz okazałe ziemie, przepastne morza, wartkie strumienia, rozległe wiatry, porywcze płomienie, bieg gwiazd, zwinną gonitwę ciał niebieskich. Jakież to szczęście - synu - jakaż wspaniałość, gdybyś w mgnieniu oka mógł ogarnąć wzrokiem wizję rozświetlonego korowodu całego wszechświata, gdybyś mógł ujrzeć w ruchu nieporuszonego stwórcę, skrytego, a zarazem widocznego" (TS).

$87 \mathrm{~W}$ nawiasie kwadratowym umieszczam pojedyncze słowa, których Biernat z Lublina nie uwzględnił w manuskrypcie. W nawiasie okrągłym oznaczam natomiast to, co znajduje się w manuskrypcie, lecz nie ma w edycji Campanelliego. „[Spójrz] i na siedem rozstawiających się światów, stworzonych $\mathrm{w}$ cudownym ornamencie, $\mathrm{w}$ wiecznotrwałym porządku, każdy swym obiegiem wypełnia kolejną epokę, każdy z osobna przepełniony światłem, choć ogień ich nie sięga. Zgodność przeciwieństw i jedność różnic, kształty rozjaśniające wśród promieni pochodzących od boga, stworzyciela wszelkiego dobra, stwórcy całego porządku i wiecznego przywódcy siedmiu światów. Księżyc mknie wśród nich na przedzie jako narzędzie natury przemieniające niższą materię. Ziemia usadowiona w środku wszechświata, siedlisko kosmicznego piękna, karmicielka wszystkich ziemskich stworzeń, [ich żywicielka]. Przeniknij w rozliczne zastępy śmiertelnych, jak i nieśmiertelnych oraz pomiędzy nich, jakby na progu, gdzie księżyc swym obiegiem otacza i śmiertelne, i nieśmiertelne". 
illis nullo modo - amicitia enim contrariorum dissimiliumque commixtio lumen instituit, illustratum ab actu dei, bonorum omnium genitoris, totius ordinis principis septemque mundorum ducis eterni - lunam vero ceteris precurrentem, nature organum, inferiorem materiam transmutantem; terram in mundi medio sitam, pulchri mundi subsellium, nutrimentum terrenorum omnium, [eandemque nutricem]. Meditare numerum mortalium (videlicet atque) immortaliumque [viventium], medium vero quasi confinium utrorumque, mortalium videlicet atque immortalium, lunam ipsam circumeuntem (Campanelli ed., 73-74.68-81); (A, 24r-v).

Zarówno passus z C. H. V.5 jak i passus z C. H. XI.7 powstały głównie $\mathrm{z}$ inspiracji platońskim Timajosem i stoicką afirmacją kosmosu. Jeden i drugi przedstawiają piękno wszechświata przez metaforyczny lot poprzez uniwersum. Obie partie tekstu zmierzają do medytacji na aktem stwórczym. Jednakże w kontekście całego wywodu kontemplacja ta wynika z różnej inicjacji poznawczej. $\mathrm{W}$ fragmencie $\mathrm{z} \mathrm{V}$ rozdziału Hermes Trismegistos wyjaśnia egipskiemu Thatowi, iż umysłowe poznanie (gr. noēsis; łac. intellectio) widzialnego kosmosu prowadzi do „wiedzy” (gr. gnōsis; łac. cognitio) o niewidzialnym Bogu ${ }^{88}$. Człowiek poznaje najpierw zróżnicowane zjawiska świata, aż wreszcie staje przed pytaniem: „Któż nadał kształt każdemu z nich ${ }^{89}$ ?" (TS) - "Quis nam singula finxit?” (Campanelli ed., 40.76). W ten sposób dochodzi do wiedzy o niewidzialnym, niezrodzonym, nienazywalnym Bogu. Ten sam sposób rozumowania przedstawia Trismegistos Asklepiuszowi w rozdziale C. H. XIV.2 (Campanelli ed., 107.12-16). Biernat z Lublina jednakże nie uwzględnił i tych sentencji. Ważniejsza była dla niego wypowiedź z rozdziału XI, gdzie sam umysł (mens) objawia przed Hermesem, iż w pierwszej kolejności jest wiedza o jednym Bogu, który jako Stwórca integruje kosmiczną wielość. Pierwszy jest wieczny Bóg, następnie czasowy świat. Oto wyjaśnienie z traktatu C. H. XI.2 przepisane z podkreśleniami na karcie 23v:

tempus, deus et universum sic se habent. Deus eternitas, tempus generatio: deus eternitatem, eternitas mundum, mundus tempus, tempus generationem efficit. Dei quasi essentia est bonum, pulchrum, beatitudo, sapientia; eternitatis, essentia ipsum idem, mundi ordo, temporis transmutatio, generationis mors et vita. Actus dei mens et anima, eternitatis perseveratio atque immortalitas, mundi institutio et restitutio, temporis augmentum et diminutio, generationis denique qualitas. Eternitas ergo in deo, in eternitate mundus, tempus in mundo, in tempore generatio (Campanelli ed., 71.9-19) ${ }^{90}$.

${ }^{88}$ Garth Fowden mówi w tym miejscu o kierunku gradacji od epistèmē do gnōsis (Fowden 103).

89 Patrz: C. H. V.7.

90 "Tak oto wygląda związek między czasem, Bogiem i światem. Bóg to wieczność, czas to cykl powstawania. Bóg stwarza wieczność, wieczność stwarza świat, zaś świat czas, a czas cykl powstawania. Dla Boga jakby esencją jest dobro, piękno, szczęście, mądrość; dla wieczności esencją jest tożsamość; dla świata ład; dla czasu przemiana; a dla cyklu powstawania śmierć i życie. Bóg wpływa na umysł i duszę; wieczność na nieprzemijalność oraz nieśmiertelność; świat na kształtowanie i prze- 
Biernat w swojej antologii w pierwszej kolejności uwydatniał wiedzę o tym, co boskie. „Wiedza” ta jest zwieńczeniem naukowego rozumowania, lecz naukowe rozumowanie jako dar pochodzi od Boga ${ }^{91}$. Biernat z Lublina akcentował silniej mistyczny sensus divinus, który poprzedza racjonalizujący sensus mundanus.

Jednocześnie - na podstawie wyżej przedstawionych cytatów - możemy zauważyć, że pojęcie sensus oznacza też pewnego rodzaju „zmysł poznawczy” charakterystyczny dla kontemplacji. Dopiero akt kontemplacji integruje hierarchiczną relację między Bogiem a światem. Kontemplacja zaś to umiejętność i działalność właściwa dla człowieka. Uczestniczy bowiem człowiek zarówno w kosmicznym cyklu powstawania, jak i współistnieje w boskiej wieczności. Zatem kontemplacja nie może być $\mathrm{w}$ tym miejscu rozumiana jedynie jako bierna medytacja nad pięknem boskiego świata, lecz przede wszystkim jako aktywna działalność, która określa status ontyczny człowieka, jego tożsamość oraz godność. Treści te wynotował Biernat między innymi z XI rozdziału Asclepiusa92.

Poznawać i kontemplować jednego Boga oraz sprawować opiekę nad rozmaitymi stworzeniami świata to główne zadania człowieka, jakie Biernat z Lublina akcentował podczas lektury pism hermetycznych. Przyjrzyjmy się jednak uważniej, w jaki sposób zachowywał on fragmenty hermetyczne, odnoszące się do człowieka. Które dicta Hermetis miały według Biernata najistotniejsze znaczenie dla humanitas?

\section{Mensura hominis ${ }^{93}$}

Wartość człowieka, jego pochodzenie, zadania oraz cele nie zostały w pismach hermetycznych określone w sposób normatywny. Nie tyle mówimy tu o przykazaniach, co o objawieniach. Tajemnicze cienie i opary, metafory pędzącego wodospadu i źródlanych wód, ulotnej iskry, światła wśród ciemności ${ }^{94}$, a przede wszyst-

kształcanie; czas na wzrost i zanik; natomiast cykl powstawania na jakość. Zatem do Boga przynależy wieczność, do wieczności świat, do świata czas, do czasu cykl powstawania" (TS).

${ }^{91}$ Patrz dicta C. H. X.9 przepisane na karcie 21v: „cognitio scientie terminus, scientia dei donum” (Camapanelli ed., 63.97); „,wiedza to cel nauki, nauka to dar Boga” (TS).

${ }_{92} \mathrm{Na}$ karcie 2v manuskryptu Biernata z Lublina czytamy: „hunc ergo sic effectum conformatumque \& tali ministerio obsequioque praepositum a summo deo, eumque conpetenter munde mundum servando, deum pie colendo, digne \& conpetenter in utroque dei voluntati parentem (Ed. Rom., 151v.10-14). Por: Ascl. XI (NF II, 310.10-14). „Został on [człowiek] przecież tak wspaniale przez stwórcę uczyniony i ukształtowany, a najwyższy bóg mu powierzył tak wielkie zadanie. Posłuszny woli boga, współuczestniczy w dziele zachowywania świata we właściwym porządku i sprawuje pobożnie kult boga, w obu tych sprawach wypełniając godnie i właściwie jego wolę" (Pseudo-Apulejusz 185).

${ }^{93}$ Patrz: przypis nr 137.

${ }_{94}$ Por: C. H. I.4; C. H. I.28; Ascl. III; Ascl. XIX; C. H. X.18; Ascl. XXIX; C. H. I.6; C. H. III.1. 
kim aforystyczny charakter wypowiedzi stwarzają nastrój wtajemniczania do określonego sposobu bycia. Etyka hermetyczna nie stosuje parenetycznych sformułowań. Stwarza natomiast pewnego rodzaju aurę, która wywołuje impuls etyczny lub jeszcze innymi słowy: pobudza zmysł moralny wkomponowany pierwotnie w zaczątek człowieka ${ }^{95}$. Stąd tak ważne dla hermetyzmu są objawienia skoncentrowane na rozpoznaniu człowieczego miejsca w hierarchii bytów, poznaniu ludzkich możliwości i mocy kreacyjnych, wiedzy o duchowym doznaniu przekraczającym tymczasowość egzystencji i umiejętność wejścia w sferę wieczności, czyli wiedza o boskim rodowodzie człowieka.

Nie sposób, żeby Biernat z Lublina pomijał te treści. Co więcej - przy fragmentach odnoszących się do człowieka - to właśnie hermetyczna paideia ${ }^{96}$ została najwyraźniej zaakcentowana w Biernatowym manuskrypcie. Precyzyjnie podkreślane aforyzmy wskazują, że istotne dla niego było konkretne przesłanie na temat człowieka. Dicta Hermetis przepisane do antologii stawały się w ten sposób pewnym zaczynem postępowania, które jako filozoficzne ziarno ${ }^{97}$ ożywiało humanistyczny wzorzec - paradygmat dla praktycznego stosowania objawionej prawdy. W ten sposób hermetyzm stanowił macierzysty kontekst dla idei humanistycznych.

Punkt centralny, wokół którego rozsiane są hermetyczne opisy człowieka, stanowi koncepcja homo perfectus - idea człowieka kompletnego i całkowitego; człowieka, który istnieje jako złączenie wszelkich kosmicznych fenomenów, jako suma duchowo-cielesnych doświadczeń pośredniczy między światem górnym i dolnym; kształtuje materię, pielęgnuje naturę, współtworzy cykl życia, i tym samym współuczestniczy z boską niewyrażalną dobrocią. Idea homo perfectus - inspirowana w myśli europejskiej przede wszystkim przesłaniami biblijnymi, platońskimi i stoickimi - znalazła swą syntezę w tradycji hermetycznej. Od starożytności poprzez wieki średnie wielokrotnie pobudzała rozważania o tożsamości człowieka, jego wolności, godności oraz jego marności (Domański 1997: 93-122). Powrót do tekstów hermetycznych w XV wieku nadał tej idei większego impetu, który ożywił myślenie o człowieku jako stworzeniu kompletnym, konstytuującym w wolności pełnię istnienia: człowiek złożony z natury śmiertelnej i nieśmiertelnej jako „stworzenie boskie"98, ukształtowany na „obraz Boga”99, kontempluje Jego dzie$\mathfrak{ł a}^{100}$, łączy się z nimi więzami miłości ${ }^{101}$, zarazem całą swą świadomością jednoczy

95 Por: C. H. XIII.10.

${ }^{96} \mathrm{Na}$ temat terminu „hermetyczna paideia” (hermetic paideia) Patrz: Fowden 97-98. Por: McKnight 99-108.

${ }^{97}$ Patrz: C. H. XIV.10 (Campanelli ed., 111.86-92); (A, 30r).

98 C. H. X.24: „Homo siquidem animal est divinum” (Campanelli ed., 70.257-258); (A, 23r).

${ }^{99}$ Na karcie 2r czytamy: „secundum esse imaginem dei” (Ed. Rom., 151r.21). Por: Ascl. X (NF II, 308.20-21). Patrz także: C. H. I.21.

${ }^{100}$ C. H. IV.2: „Homo enim effectus est divini operis contemplator” (Campanelli ed., 31.14-15); $(\mathrm{A}, 15 \mathrm{v})$. 
się z boskim rozumem ${ }^{102}$ i tak jak Stwórca, tak też człowiek, uczestniczy w akcie tworzenia ${ }^{103}$.

Homines perfecti w swoim umyśle ogarniają wszystkie sprawy ziemskie, niebiańskie i nadniebiańskie ${ }^{104}$. Wiedza ta jest jednak przeznaczona dla "nielicznych" („paucissimi”) ${ }^{105}$, nie wszyscy bowiem - według Hermesa Trismegistosa - zostali obdarowani (donum dei; divinum munus) umysłem (mens) i zmysłem poznawczym (sensus) ukierunkowanym na rozumienie bezgranicznej pełni. Nie tyle chodzi tutaj o status adepta wyjątkowego, wtajemniczonego, lecz o to, że nie wszyscy są w stanie przyjąć tę wiedzę i trwać w niej. Stąd też w tekstach hermetycznych pojawiają się liczne wtrącenia o nierozumnym zmyśle (sensus irrationalis) ukierunkowanym na ograniczone zezwierzęcenie ${ }^{106}$. Na karcie $1 \mathrm{v}$ podkreślił Biernat z Lublina takie zdania z VII rozdziału Asclepiusa:

Non omnes, o Asclepi, intellegentiam veram adepti sunt, sed imaginem temerario inpetu nulla vera ratione inspecta sequentes decipiuntur, quae in mentibus maliciam parit et transformat optimum animal in naturam ferae moresque bestiarum (Ed. Rom., 150r.17-20) ${ }^{107}$.

Na marginesie wynotował homo duplex animal zgodnie z kolejną przepisaną z tego rozdziału sentecją: "Solum enim animal homo duplex est” (Ed. Rom., 150r.22) ${ }^{108 " . ~ H o m o ~ d u p l e x ~ s t a n o w i ~ w ~ h e r m e t y z m i e ~ e k w i w a l e n t ~ d l a ~ p o j e ̨ c i a ~ h o m o ~}$ perfectus, lecz nie tylko ukazuje dramatyczne rozdarcie człowieka między skończonością, a nieskończonością, prezentuje raczej całkowitość człowieka, jego dynamiczną tożsamość oraz twórczą aktywność $\mathrm{w}$ roli pośrednika między Bogiem i światem. Odczytajmy w tym miejscu zdania z VIII rozdziału Asclepiusa zapisane w manuskrypcie na karcie 2 r:

Itaque hominem conformavit ex animi atque corporis id est ex aeterna atque mortali natura, ut animal ita conformatum utrique origini suae satisfacere possit, et mi-

101 Patrz: A, 1v: „nexu secum caritatis adstringit” (Ed. Rom., 149v.27-28). Por Ascl VI (NF II, 302.9-10).

102 Patrz: A, 7v: „toto se sensu intelligentiae divinae commiscet” (Ed. Rom., 156v. 7-8). Por: Ascl. XXIX (NF II, 336.8-9).

103 C. H. I.12-13. Patrz: Campanelli ed., 10-11.78-84; A, 12r.

${ }^{104}$ C. H. IV.5. Patrz: Campanelli ed., 32.38-43; A, 16r.

105 Patrz: A, 2r (Ed. Rom., 150v.37). Por: Ascl. IX (NF II, 307.14).

106 C. H. IV.5. Patrz: Campanelli ed., 32.34-35; A, 15v.

107 Por: Ascl. VII (NF II, 303.23-27). „Nie wszyscy, Asklepiuszu, są zdolni do prawdziwego rozumienia rzeczywistości. Nie dostrzegając istoty żadnych spraw, dają się oszukiwać, co rodzi zło w ich sercach i zmienia to najlepsze wszak ze wszystkich stworzeń ożywionych w dzikie zwierzę, a jego charakter - w charakter jakiejś potwornej bestii" (Pseudo-Apulejusz 180).

108 Por: Ascl. VII (NF II, 304.1-2). „Spośród wszystkich stworzeń ożywionych jedynie człowiek jest dwoisty" (Pseudo-Apulejusz 180). 
rari atque orare \& aeterna caelestia, incolere atque gubernare terrena (Ed. Rom., 150v.13-16) ${ }^{109}$.

Przypomnijmy też słynny fragment z VI rozdziału Asclepiusa przepisany na karty 1r-v antologii:

Propter hoc, o Asclepi, magnum miraculum est homo, animal adorandum atque honorandum. Hoc enim in naturam dei transit, quia ipse sit deus; hoc demonum genus novit, utpote qui cum isdem ortum se esse cognoscat. Hoc humane nature partem in seipso despicit, alterius partis divinitate confisus. $\mathrm{O}$ hominum quanta est natura temperata felicius! diis cognata divinitate coniunctus; partem sui, qua terrenus est despicit; cetera omnia quibus se necessarium esse caelesti dispositione cognoscit, nexu secum caritatis astringit; sicque suscipit celum. sic ergo feliciore loco medietatis est positus, ut, que infra se sunt, diligat, ipse a superioribus diligatur. colit terram, elementis velocitate miscetur, acumine mentis in maris profunda descendit. omnia illi lucent; non caelum videtur altissimus; quasi enim proximo enim sagacitate animi intuetur (Ed. Rom., 149v.20-32) $)^{110}$.

Biernat z Lublina wynotowywał niemal wszystkie dicta Hermetis, które przedstawiają dwoistość człowieka złożonego z tego, co światowe (ziemskie, cielesne, czasowe, śmiertelne) - pars mundana - i z tego, co boskie (niebiańskie, duchowe, wieczne, nieśmiertelne) - pars divina; zarówno z Corpus hermeticum ${ }^{111}$ jak i z Ascle-

${ }^{109}$ Dicta z edycji NF II różnią się nieznacznie od Ed. Rom.: „itaque hominem conformat ex animi atque corporis id est ex aeterna atque mortali natura, ut animal ita conformatum utraeque origini suae satisfacere possit, et mirari atque adorare caelestia et incolere atque gubernare terrena" (NF II, 306.2-7). „Tak oto ukształtował człowieka jako złożonego z ducha i ciała, to jest z substancji wiecznej i śmiertelnej, aby stworzona $\mathrm{w}$ ten sposób istota mogła zadośćuczynić swemu dwojakiemu pochodzeniu i powołaniu: oddawać hołd i wielbić to, co niebiańskie, a zarazem sprawować opiekę i rządy nad tym, co śmiertelne" (Pseudo-Apulejusz 181).

110 Ponieważ przekład Kazimierza Pawłowskiego powstał na podstawie edycji NF II, która znacznie różni się od Editio Romana, podaję w tym miejscu tłumaczenie własne: „Tym samym, Asklepiuszu, jakże wielkim cudem jest człowiek, stworzeniem godnym szacunku i wyróżnienia. Oto w boską naturę się przemienia, gdyż sam bogiem jest; oto o demonach się wywiedział, gdyż dostrzega wspólne z nimi pochodzenie; oto człowiek, który przewyższa swą cząstkę o naturze ludzkiej i pokłada zaufanie do swej cząstki boskiej. Ach, o ileż pomyślniej natura człowieka została sporządzona! Z bogami się jednoczy dzięki boskiemu poznaniu. Swą ziemską cząstkę przewyższa w sobie, a z wszystkim tym pozostałym, z czym rozpoznaje swą nieuniknioną współzależność od mocy niebiańskiej, związuje się $\mathrm{w}$ łańcuchu miłości. I tak to $\mathrm{z}$ dołu ku niebu spogląda. Zatem $\mathrm{w}$ takim oto pomyślniejszym położeniu się znajduje - pośrednim, aby wielbił to, co poniżej, i był uwielbiony przez to, co powyżej. Ziemię uprawia, spleciony z szybkim działaniem żywiołów, dzięki bystrości umysłu ku morskim głębinom zstępuje. Wszystko przed nim się rozświetla. Niebo nie zdaje mu się za wysokie, jakby w bliskości przenika do niego spojrzeniem swej myśli". Por: NF II, 301.18-19 - 302.1-16; Pseudo-Apulejusz 178.

111 Patrz: A, 12r. Por: C. H. I.15 (Campanelli ed., 12.109-115). Patrz także: A, 15v-16r. Por: C. H. IV.5 (Campanelli ed., 32.34-45). Patrz także: A, 20r. Por: C. H. VIII.5 (Campanelli ed., 50-51.48-52). Patrz także: A, 26r-v. Por: C. H. XII.2-4 (Campanelli ed., 83-84.11-38). 
piusa112: Nie uwzględnił jedynie podobnych wypowiedzi z VII i XI rozdziału Asclepiusa113, które zakorzeniają „światową cząstkę" człowieka w czwórcy (Ascl. VII quadruplex; Ascl. XI - quaternis elementis formatum), czyli w czterech żywiołach (Scott 1985c: 45). Ten wybór był precyzyjny i celowy. Pojawia się więc pytanie, na jakiej podstawie dokonany? Być może Biernat z Lublina jako chrześcijański czytelnik pism hermetycznych nie zawarł owych dwóch fragmentów, kierując się przestrogami św. Pawła z Listu do Kolosan 2, 8: „Baczcie, aby kto was nie zagarnął w niewolę przez tę filozofię będącą czczym oszustwem, opartą na ludzkiej tylko tradycji, na żywiołach świata, a nie na Chrystusie". Również św. Augustyn uznawał "pisma filozoficzne oparte na żywiołach tego świata” za "pełne fałszów i czczych urojeń" (św. Augustyn 2009: 213). Możemy również zakładać, że Biernata z Lublina interesowała przede wszystkim taka koncepcja „człowieka dwoistego", która konsoliduje całokształt człowieka. Unikał więc kolejnych pojęciowych uszczegółowień, które mogłyby też sugerować sztuczne rozwarstwienie - czy to duszy, czy ciała - oraz parcelację ludzkiej wewnętrznej integralności. Jednakże, by móc kontynuować tę myśl, przywołajmy szerszy kontekst filozoficzny, który odwołuje się do hermetycznego homo duplex.

Naucza więc Trismegistos, że człowiek po części boski, po części śmiertelny, wstępuje ku boskim wyżynom ${ }^{114}$ lub „pod ciężarem swego ciała zniża się do gorszego rozumienia świata11", pokłada zaufanie w mającą nadejść nieśmiertelność116 lub poddaje się „zawistnemu wobec nieśmiertelności złu117”, obdarowany rozum-

112 Patrz: A, 1r-v (Ed. Rom., 149v, 20-32). Por: Ascl. VI (NF II, 301.18-19-302.1-16); (PseudoApulejusz 178). Patrz także: A, 1v-2r (Ed. Rom., 150v.13-16). Por: Ascl. VIII (NF II, 306.2-7); (PseudoApulejusz 181). Patrz także: A, 2r (Ed. Rom., 150v.37-38-151r.1-3). Por: Ascl. IX (NF II, 307.14-19); (Pseudo-Apulejusz 182-183). Patrz także: A, 2r-v (Ed. Rom., 151r.18-28). Por: Ascl. X (NF II, 308.16-26309.1-4); (Pseudo-Apulejusz 183-184). Patrz także: A, 3v (Ed. Rom., 151v.29-33). Por: Ascl. XII (NF II, 311.11-16); (Pseudo-Apulejusz 186). Patrz także: A, 5v (Ed. Rom., 154r. 23-38-154v.1-6). Por: Ascl. XXII (NF II, 323. 21-25-324.1-25); (Pseudo-Apulejusz 197-198).

113 Patrz: Ed Rom., 150r.24-29. Por: Ascl. VII (NF II, 304.4-10); (Pseudo-Apulejusz 180). Patrz także: Ed. Rom., 151v. 2-7. Por: Ascl. XI (NF II, 309.21-23-310.1-6); (Pseudo-Apulejusz 185).

114 Patrz: A, 1r: „prope deos accedit, qui se mente, qua diis iunctus est, divina religione diis iunxerit" (Ed. Rom., 149v.16-17). Por: Ascl. V (NF II, 301.12-14); (Pseudo-Apulejusz 177-178).

115 Patrz: A, 2r:,,in inferiorem intellegentiam mole corporis resederunt". Rękopisy zapisują w tym zdaniu słowo „inferiorem” (niższy, gorszy), jednakże Editio Romana (Ed. Rom. 151v.1-2) „interiorem” (głębszy, bardziej wewnętrzny). Edycja Paula Thomasa, Waltera Scotta oraz NF II uwzględniają tę różnicę w aparacie krytycznym za uwagami Heinricha Koziela. Patrz: Ascl. IX: (Thomas ed., 45); (Scott ed., 1985a: 302); (NF II, 307.17-18); (Pseudo-Apulejusz 183).

116 Patrz: A, 1r: „immortalitatis future concipit fiduciam” (Ed. Rom., 156v. 9). Por: Ascl. XXIX (NF II, 336.10-11; Pseudo-Apulejusz 206).

117 Patrz: A, 3r: „invidens immortalitati malignitas” (Ed. Rom., 151v.32-33) Por: Ascl. XII (NF II, 31.15-16); (Pseudo-Apulejusz 186). Na karcie 22r przepisał korespondujące dicta z C. H. X.12: „Mundus enim non bonus, quia mobilis, non tamen malus, quoniam immortalis; homo autem, tum quia mobilis, tum etiam quia mortalis, malus esse censetur” (Campanelli ed., 64.127-130). „Świat - ponieważ odzna- 
ną mową oraz umysłem ${ }^{118}$ zbliża się do boskości119, albo namówiony do wojen, grabieży i oszustwa łączy się wraz z posłańcami zniszczenia ${ }^{120}$; człowiek kroczy ku wieczności „boską drogą ${ }^{121 ”}$ przyobleczony w szatę „żywej śmierci'122”, niebezpiecznie balansuje ${ }^{123}$ na fali przypływu i odpływu ${ }^{124}$, między widzialnym i niewidzialnym ${ }^{125}$, na progu światła i ciemności ${ }^{126}$; człowiek rozpięty między stwórczym

cza się ruchem - nie jest dobrem, lecz nie jest też złem, gdyż jest nieśmiertelny. Człowiek natomiast gdyż odznacza się i ruchem i śmiertelnością - postrzega się jako zło" (TS). Patrz także: C. H. IX.4.

118 C. H. XII.12: "largitus est scilicet sermonem atque mentem” (Campanelli ed., 88.113-114); (A, 27r). Por: Ascl. XLI oraz C. H. IV.3.

119 C. H. XII.1: „humanitas divinitati proxima” (Campanelli ed., 83.7-8); (A, 26r).

120 Patrz: A, 6r: „nocentes angeli, qui humanitate commixti” (Ed. Rom., 155v.1). Por: Ascl. XXV (NF II, 329.15); (Pseudo-Apulejusz 202).

${ }^{121}$ C. H. XI.21: "via divina”" (Campanelli ed., 81.227); (A, k. 25v).

122 C. H. VII.2: "viva mors" (Campanelli ed., 47.19); (A, 19v). Patrz też: C. H. I.28 (Campanelli ed., 18.234-239); (A, 13r).

123 Słowo periclitari - zastosowane w Ascl. XII - znaczy zarówno „doświadczać” oraz „być w niebezpieczeństwie”.W Editine Romana (Ed. Rom., 151v.27-28) czytamy: „animae in humana vita periclitantur". Biernat z Lublina pomija w tym miejscu słowo "animae” (A, 3r). Warto również dodać, że zarówno wydania Paula Thomasa (Thomas ed., 48), Waltera Scotta (Scott ed., 1985a: 308) oraz Nocka i Festugière'a (NF II, 311.8-9), nie uwzględniają w aparacie krytycznym dicta z Editine Romana i podają: „animae in mundana vita periclitantur”. Na tej podstawie Kazimierz Pawłowski tłumaczył: „dusze są poddawane próbie ziemskiego życia" (Pseudo-Apulejusz 186).

124 Walter Scott (Scott 1985b: 184) akwatyczną metaforę z C. H. VII.1-2 wyjaśnia porażką duszy, która - poddana ciału - nie potrafi dotrzeć do sanktuarium. Brian Copenhaver (Copenhaver ed., 146) przypomina interpretację Charlesa Harolda Dodda, który dostrzega aluzję do biblijnego potopu. Warto też zauważyć analogiczną metaforę w Timajosie Platona (43 a-b), gdzie mowa jest o "ciele podlegającym odpływowi i zasilanemu przypływem. Dusze, wpuszczone w wielki nurt ciała, ani zapanować nad nim nie umiały, ani mu nie uległy całkowicie, ale gwałtowny prąd je ponosił i one ponosiły, tak że się cała istota żywa poruszała bez porządku, w byle jakim kierunku, szła bez żadnego sensu" (Platon 321). Obraz ten powraca też za Platonem w średniowieczu, gdy Bernard Silvestris pod alegorią Silvy opisuje nieskoordynowaną materię (Cosmographia. I, 1, 25): "Quando fluit refluitque sibi contraria moles” („Przypływ i odpływ bez dna, masa w sobie sprzeczna” [TS]). Patrz: (Bernard Silvestris 97).

${ }^{125}$ C. H. IV.9: arduum autem est consueta atque [A: ac] presentia relinquentem ad superiora se potioraque convertere. Illa enim que oculis cernimus nimium nos delectant, latentia diffidentiam pariunt. Patentia [A: add. autem] sane mala sunt, bonum occultum iis [A: hiis] qui manifestis incumbunt; neque [A: nec] enim forma eius ulla, neque [A: nec] figura. Hac de causa sui tantum simile, ceterorum [A: ceteris horum] vero dissimile; etenim corpori incorporeum apparere non potest (Campanelli ed., 34.79-86). W nawiasie kwadratowym odnotowuję różnice, jakie występują w manuskrypcie Biernata (A, 16v). "Niełatwo przychodzi nam pozbycie się zastanych nawyków, by ukierunkować się ku temu, co wyższe i znaczniejsze. Zbytnio delektujemy się tym, co roztacza się przed naszymi oczami, a widoki te wzbudzają w nas brak wiary, ta sceneria zła, która swym rażącym przedstawieniem przykrywa dobro - dobro, które przecież nie ma ani formy, ani kształtu, a ponieważ upodabnia się jedynie do samego siebie, niepodobne jest z niczym innym. Dlatego też nie może bezcielesne objawić się temu, co cielesne" (TS). Por: C. H. V.1-2.

${ }^{126}$ C. H. VII. 2. Patrz: Campanelli ed., 47.11-12; A, 19v. 
bogiem $^{127}$, a zwierzęcym instynktem ${ }^{128}$, zmieszany z dobrem i złem ${ }^{129}$, przyczynia się do dobra i zła ${ }^{130}$.

W dziejach filozofii różnie systematyzowano naukę Trismegistosa o dwoistości natury ludzkiej. Różnie też rozkładano akcenty. Nie sposób w tym miejscu przywołać rozmaitość tych interpretacji. W bliskim Biernatowi z Lublina średniowieczno-renesansowym kontekście najsilniej eksponowano niezbywalną pełnię człowieka - „integritas” (Hugo de St. Victore 128-130)131, duchową jedność, ku której człowiek wstępuje w swej wolnej egzystencji (Giovanni Pico della Mirandola 58), „jedność z Najwyższym” (Mikołaj z Kuzy 176), „człowiek jako spoiwo między Bogiem i światem ${ }^{132 "}$. W obrębie tej idei hermetyzm nie stanowił żadnej kontrowersji dla chrześcijaństwa ${ }^{133}$. Jedność Boga (unitas Dei; monada) oraz całkowitość człowieka (homo perfectus) to wiedza przekazywana zarówno w obrębie tradycji chrześcijańskiej, jak i platońskiej ${ }^{134}$ oraz hermetycznej. Idea ta prowadziła również do fuzji średniowiecznego i renesansowego humanizmu. W nawiązaniach tych uczestniczył także Biernat z Lublina, co zauważamy właśnie w jego praktyce czytelniczej. Polski filozof wielokrotnie przepisywał więc i podkreślał passusy mówiące o duchowej pełni człowieka, która według hermetyzmu jest identyczna z boskością i która integruje ludzką śmiertelność oraz nieśmiertelność. Oto słynna sentencja kończąca $X$ traktat Corpus hermeticum zaznaczona przez Biernata w manuskrypcie na kartach 23r-v:

Quamobrem audendum est dicere hominem quidem terrenum deum esse mortalem, deum vero celestem immortalem hominem. Itaque horum virtute duorum, hominis scilicet ac mundi, gubernantur singula; uni demum cuncta subiiciuntur (Campanelli ed., $70.269-271)^{135}$.

${ }^{127}$ C. H. I.13. Patrz: Campanelli ed., 10-11.73-86; A, 12v. Patrz także: C. H. V.3: Campanelli ed., 38.31-32; A, 17r.

128 Patrz: A, 1v (Ed. Rom., 150r.17-20). Por: Ascl. VII (NF II, 303.23-27). Patrz także: C. H. XII.2 (Camapnelli ed., 83.11-20); (A, 26r).

129 Patrz: C. H. VI.3 (Campanelli ed., 44.39-42); (A, 19r). Patrz także: C. H. VI.6 (Campanelli ed., 46.81-93). Biernat z Lublina nie przepisał tych dicta.

${ }^{130}$ C. H. IV , 8. Patrz: A, 16r: „Deus profecto extra culpam: malorum a nobis causa venit; nam mala bonis anteponimus" (Campanelli ed., 33.69-71). „Z pewnością to nie w Bogu jest wina, to my odpowiadamy za zło, gdyż przedkładamy zło ponad dobro" (TS). Ten fragment nauki Trismegistosa - jak podaje Walter Scott (Scott 1985b: 148) - ma swoje źródło u Platona (Państwo X, 617e oraz Timajos 42d). Sentencje te Biernat oznaczył w swoim indeksie pod określeniem „przyczyny zła” („malorum causa”).

${ }_{131}$ Aluzję do Asclepiusa w tym fragmencie (Didascalicon I, 5) omawia Jerome Taylor (Taylor 184).

132 ",homo nexus est Dei et mundi". Patrz: (Porreca 268-270).

133 Por: Nowy Testament: $M t, 5,48$; I Cor 2, 6; I Cor 15, 45-49.

134 Por: Platon. Timajos 51e-52a (Platon 329).

135 „Z tego powodu musimy ośmielić się powiedzieć, że człowiek na ziemi zaiste jest śmiertelnym

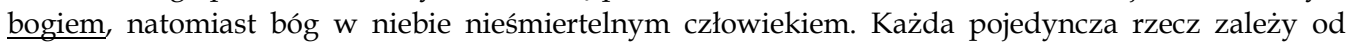


Biernat przy lekturze pism hermetycznych postrzegał humanitas przede wszystkim $\mathrm{w}$ ramach idei homo perfectus. Stąd też brak w antologii wyjaśnienia z IV rozdziału Asclepiusa 136, gdzie Trismegistus w duchu stoicko-platońskim przedstawia pojęcie humanitas jako „nieśmiertelną ludzkość”, czyli jako rodzaj, w ramach którego dzięki prokreacji zachowywane są śmiertelne jednostki - innymi słowy humanitas jako "trwała idea człowieczeństwa, łącząca nietrwałe istnienia ludzkie" (Pawlak 180). Brak też podobnego wykładu z XXI rozdziału Asclepiusa. Wybór Biernata z Lublina nie podlegał też perspektywie przyrodoznawczej (philosophia naturalis). Natomiast z całą pewnością możemy powiedzieć, że dicta Hermetis rozsiane $\mathrm{w}$ manuskrypcie mają charakter filozofii moralnej (philosophia moralis). Hermetyczna humanitas dla Biernata z Lublina to przede wszystkim paideia nauczająca, jak osiągnąć pełnię człowieczeństwa. Między innymi w tym celu autor antologii wyraźnie wyznaczał sentencje, które mówią o boskiej jedności, o zadaniu opiekowania się światem oraz o pośredniczącej i podwójnej naturze człowieka. Podkreślał aforyzmy, które wyraźnie rozróżniały nietrwałą i marną cząstkę od cząstki wiecznej i twórczej. Przede wszystkim uwypuklał dysproporcję między duchowym oddaniem (religio), a cielesną zachłannością (cupiditas; voluptas), między pobożnością (pietas), a bezbożnością (impietas) oraz między wiedzą (cognitio), a niewiedzą (ignorantia). Oto wypis z Ascl. XI o stoickiej proweniencji, podkreślony $\mathrm{w}$ antologii na karcie $2 \mathrm{v}$ : "Est autem mensura eius utriusque, id est hominis, ante omnes religio, quam sequitur bonitas. Ea demum tunc videtur esse perfecta,

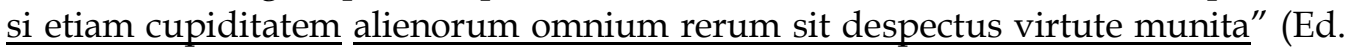
Rom., 151r.28-31)137. Dzięki dokładnym podkreśleniom mógł Biernat swobodnie i szybko poruszać się po tekście. Jednocześnie precyzował on etyczny wykład Trismegistosa w jednym moralizującym aforyzmie. Na przykład: z C. H. VI.5-6 przepisał tylko jedną sentencję. Pominął tutaj cały wykład poprzedzający i następujący tuż po wybranych dicta i zachował jedynie konkluzję: "Si deum quesieris, pulchritudinem ipsam queres; quae tandem ad id ferat unica via est, pietas cognitioni

czynu tych dwóch, człowieka i świata, lecz ostatecznie wszystko podlega jednemu” (TS) Por: C. H. XII.1: „etenim bonus demon deos quidem predicat immortales homines, homines autem mortales deos" (Campanelli ed., 83.8-10). „Powiada zatem dobry demon, iż bogowie są nieśmiertelnymi ludźmi, a ludzie śmiertelnymi bogami” (TS). Biernat z Lublina nie uwzględnił jednakże tego jednego zdania, chociaż znajduje się ono w samym środku przepisywanego wykładu z C. H. XII.1-4 (Campanelli ed., 83-84.2-38). Patrz: A, 26r-v. Decyzja ta z pewnością wynikała z tego, iż konsekwentnie pomijał on fragmenty na temat demonów.

136 "homo mortalis sit, immortalis humanitas” (Ed. Rom., 149v.1). Por: Ascl. IV (NF II, 300.18). "Człowiek jest śmiertelny, nieśmiertelna jest ludzkość" (Pseudo-Apulejusz 177).

137 Por: NF II, 309.5-9. „Wartość człowieka, w obu jego [częściach], polega przede wszystkim na duchowym oddaniu, tuż za którym podąża dobroć. A ta dopiero wówczas będzie uznana za doskonałą, jeśli człowiek, obwarowawszy się cnotą, stanie się niewzruszony wobec zachłanności wszystkich rzeczy dla niego obcych" (TS). Por: Pseudo-Apulejusz 184. 


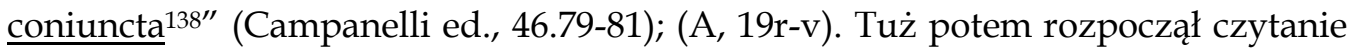
VII rozdziału Corpus hermeticum, uwydatniając jego tytuł podkreśleniem i majuskułą: "SUMMUM MALUM HOMINIBUS IGNORARE DEUM ${ }^{139 " ~(C a m p a n e l l i ~ e d ., ~}$ 47.1-2); (A, 19v), natomiast na karcie 26r podkreślił sentencję "Morbus animae gravissimus impietas est ${ }^{140 "}$ (Campanelli ed., 84.27).

Podobnych podkreśleń pojawia się więcej ${ }^{141}$. Możemy stąd przyjąć, że lektura pism hermetycznych, jaką przeprowadził Biernat z Lublina, jest - posługując się terminologią średniowiecznego augustynianina Hugona od św. Wiktora - lekturą tropologiczną. Hugon w swojej Sztuce czytania nauczal, że „tropologia, czyli interpretacja moralna142" (Hugo de St. Victore 384), jest zwieńczeniem lektury historycznej i alegorycznej, ostatecznym przyozdobieniem czytanego dzieła (Hugo de St. Victore 360$)^{143}$. W ten też sposób ukonkretniał swoją lekturę Biernat z Lublina ${ }^{144}$. Manuskryptem posługiwał się jako podręcznym zestawem najważniejszych sentencji, które wybierał $\mathrm{w}$ ramach filozofii moralnej. $\mathrm{Z}$ etyki hermetycznej czerpał naukę o dewaluacji tych aspektów świata materialnego, które potencjalnie dezintegrują dążenia człowieka na drodze poznawania. Wydobywał te pouczenia, które kierowały w stronę twórczych możliwości człowieka, możliwości identycznych jak te, które człowiek otrzymał w momencie swego duchowego powstania na obraz Boga. Akcentował więc mistyczne i kontemplacyjne złączenie z jednym Bogiem Stwórcą zróżnicowanej wielości - oraz zdolność człowieka do transcendencji ponad swe wyłącznie cielesne roszczenia i ograniczenia. Wyróżnił w tym celu hermetyczną koncepcję człowieka kompletnego, który duchowo zakorzeniony

138 „Jeśli byłbyś w stanie zrozumieć Boga, zrozumiałbyś i piękno. Ostatecznie prowadzi ku temu jedna jedyna droga: połạczenie pobożności i wiedzy" (TS).

139 "Największym złem dla ludzi jest niewiedza o Bogu" (TS).

${ }^{140}$ C. H. XII.3. „Najgorszą chorobą duszy jest bezbożność” (TS).

${ }^{141}$ Patrz: A, 19v. Por: C. H. VII.1 (Campanelli ed., 47.6-8). Patrz też: A, 22r. Por: C. H. X.15 (Campanelli ed., 65.145-148). Patrz też: A, 5r (Ed. Rom., 154r.14-17). Por: Ascl. XXII (NF II, 323. 8-11); (Pseudo-Apulejusz 197).

142 „De tropologia, id est, moralitate”. Hugo de St. Victore, Didascalicon. VI, 5.

143 "ad ultimum consummato opere domus colore superducto vestitur". Hugo de St. Victore, Didascalicon. VI, 2.

${ }^{144}$ Te inspiracje nie koniecznie musiały być średniowieczne, lecz równie dobrze współczesne Biernatowi - renesansowe. Pico della Mirandola, obok tematu wolności i wewnętrznej integralności, również wielokrotnie wskazywał na filozofię moralną jako jedną z dróg do osiągnięcia duchowego szczęścia. Dał temu wyraz w bezpośredniej aluzji do Ascl. XII (NF II, 311.13-16). „Has manus, hos pedes, idest totam sensualem partem in qua sedet corporis illecebra quae animam obtorto (ut aiunt) detinet collo, ne a scalis tamquam prophani pollutique reiciamur, morali philosophia quasi vivo flumine abluamus”. Przekład Z. Nerczuka i M. Olszewskiego: „Obmyjmy zatem w filozofii moralnej, niczym w rzece życia, te ręce, te nogi, to znaczy: całą część zmysłową, w której mieści się cielesna podnieta, która, jak powiadają, trzyma duszę za gardło, abyśmy nieczyści i skalani nie zostali strąceni z drabiny" (Giovanni Pico della Mirandola 52-53). 
w boskiej jedności potrafi opanowywać wewnętrzne (osobowe) i zewnętrzne (światowe) zróżnicowanie.

Biernat z Lublina nie czytał pism hermetycznych jako scholastyczny komentator, egzegeta czy też historyk. Nie sięgał też bezpośrednio do hermetyzmu, gdy układał polską poezję. Czytał $\mathrm{w}$ ramach studia humanitatis, poszerzając i pogłębiając wiedzę z filozofii moralnej145. Angażował się w tę dyscyplinę już u początku swej humanistycznej działalności właśnie jako czytelnik pism Hermesa Trismegistosa, a następnie - bazując między innymi na czytelniczym doświadczeniu - jako tłumacz pouczających bajek oraz autor epimythionów. Z pewnością daleko mu było do autokreacyjnych i rewelatorskich ekscesów w stylu prorokującego poety (poeta vates). Biernat z Lublina swą lekturą okazywał raczej postawę pragmatyczną i uczoną (poeta doctus). Aforyzmy Hermesa Trismegistosa użytkował jako paideia, czyli jako krystalizację etycznego celu człowieka, to znaczy: integrowanie zróżnicowanej wielości w boskiej jedności, której obrazem jest człowiek kompletny (homo perfectus). „Omnia unius esse aut unum esse omnia” (Ed. Rom., 148v.9)146 jak głosi sentencja z początku Asclepiusa, do antologii Biernata z Lublina przepisana jako pierwsza (A, 1r).

\section{Wnioski}

Biernat z Lublina czytał pisma hermetyczne świadomy ich zróżnicowanej recepcji. Dobrze orientował się pośród głównych koncepcji hermetycznych, wiedział, które fragmenty wzbudzały największe kontrowersje, oraz które dicta Hermetis znalazły powszechną zgodę i aprobatę. Sentencje do antologii wybierał w sposób przemyślany i celowy, uważnie oraz bardzo precyzyjnie. W swoim manuskrypcie okazał efekty indywidualnej i samodzielnej lektury, a zarazem świadomie włączał się $\mathrm{w}$ określoną już tradycję rozumienia hermetyzmu. W kwestiach teologicznych kierował się przede wszystkim autorytetem św. Augustyna. Również za nim przejawiał ambiwalentny stosunek do hermetyzmu. $Z$ jednej strony bowiem wyraźnie akcentował naukę o jednym bezimiennym Bogu, o boskiej kontemplacji i mistycznym zjednoczeniu; z drugiej strony odrzucał dicta Hermetis o treści politeistycznej.

145 „Zważywszy, że filozofia moralna, w przeciwieństwie do pozostałych działów filozofii, była uważana za część składową studia humanitatis, możemy łatwo zrozumieć bliski związek renesansowej myśli moralnej z ruchem humanistycznym" (Kristeller 98).

146 Patrz: Ascl. I (NF II, 296.11-12). „wszystko należy do jednego albo jedno jest wszystkim” (Pseudo-Apulejusz 173). Biernat umieścił też krótkie podkreślenie na karcie 26v, gdy odnotował analogiczną sentencję z C. H. XII, 8: „Unum omnia sunt” (Campanelli ed., 86.73-74) - "Jednością jest wszystko" (TS) - oraz na karcie 5r odnośnie bezimienności Boga: „jest on zarazem jednym i wszystkim” (Pseudo-Apulejusz 195) - "sit unus \& omnia” (Ed. Rom., 153v.23-24). Por: Ascl. XX (NF II, 321.6-7). 
Dystansował się także do kwestii idolatrii oraz panteizmu. Na kartach manuskryptu Biernata z Lublina świat nie tyle jawi się jako przebóstwiony, lecz w swym materialnym zróżnicowaniu uzależniony od woli jednego Boga. Poznanie urozmaiconej wielości świata warunkuje inicjacja poznawcza w boskiej jedności. Zadaniem człowieka jest zdobycie owej boskiej wiedzy.

Biernat z Lublina wskazywał często na te treści, które akcentują etykę hermetyczną, czyli pouczenia o mistycznym poznaniu Boga, o opiece nad światem oraz o integralnej doskonałości człowieka w roli pośrednika między tym, co boskie i światowe. Biernat $\mathrm{z}$ Lublina łączył $\mathrm{w}$ ten sposób tradycję hermetyczną i humanizm w obrębie filozofii moralnej, w etyce tej dostrzegał także konsensusy łączące hermetyzm i chrześcijaństwo.

\title{
Wykaz skrótów
}

\begin{abstract}
A - Antologia Biernata z Lublina. Rękopis Biblioteki PAN nr 1717: Kraków.
Ascl. - Asclepius

C. H. - Corpus hermeticum

Ed. Rom. - Apuleius Madaurensis. Metamorphoseos sive de asino aureo libri XI. Romae: $1469, \mathrm{ff} .148 \mathrm{v}-159 \mathrm{v}$.

NF II - Nock Arthura Darby, Andrea Jean Festugière ed. „Asclepius”. Corpus hermeticum XIII-XVIII. Asclepius. Vol. 2. Paris: Les Belles Lettres, 1992 (première éditione 1946). S. 257-355.
\end{abstract}

\section{BIBLIOGRAFIA}

św. Augustyn. Państwo Boże. Przeł. ks. Władysław Kubicki. Kęty: Wydawnictwo Antyk, 1998. św. Augustyn. Wyznania. Przeł. Z. Kubiak. Kraków: Wydawnictwo Znak (wyd. IV, dodruk), 2009. Bernard Silvestris. Cosmographia. Ed. Peter Dronke. Leiden: E. J. Brill, 1978.

Biernat z Lublina. Ezop. Wyd. I. Chrzanowski. Kraków: Biblioteka Pisarzów Polskich nr 55, 1910.

Biernat z Lublina. Ezop. Wstęp Stanisław Grzeszczuk, oprac. Janusz S. Gruchała. Kraków: Biblioteka Polska, 1997.

Brückner, Aleksander. Ezopy polskie. Kraków: Rozprawy Akademii Umiejętności. Wydział Filologiczny (T. XXXIV), 1902.

Budzyk, Kazimierz. „'Marchołt' Jana z Koszyczek”. Ze studiów nad literatura staropolską. Studia staropolskie. T. 5. Red. K. Budzyk. Wrocław: Zakład Narodowy im. Ossolińskich, 1957. S. 81-114.

Campanelli, Maurizio. „Introduzione”. Campanelli, Maurizio ed. Mercurii Trismegisti Pimander sive de potestate et sapientia Dei. Ed. Maurizio Campanelli. Torino: Nino Aragno, 2011. S. VII-CCLV.

Campanelli, Maurizio ed. Mercurii Trismegisti Pimander sive De Potestate et Sapientia Dei. Torino: Nino Aragno, 2011.

Copenhaver, Brian P. ed. Hermetica. The Greek Corpus Hermeticum and the Latin Asclepius in a new English translation, with notes and introtaction. Transl. Brian P. Copenhaver. Cambridge: Cambridge University Press, 1992.

Domański, Juliusz. „Losy Marsilia Ficina w Polsce w XVI XVI wieku”. Philosophica, paraphilosophica, metaphilosophica. Studia i szkice z myśli dawnej. Przeł. Maria Chodyko. Karków: Polska Akademia Umiejętności, 2008. S. 369-388. 
Festugière, Andrè Jean. La révélation d'Hermès Trismégiste. T. 2. Paris: J. Gabalda, 1949.

Fowden, Garth. The Egyptian Hermes. A Historical Approach to the Late Pagan Mind. New Jersey: Princeton University Press, 1993.

Freedman, John. „Biernat of Lublin: The First Polish Writer in Vernacular”. Polish Review 3 (1985). S. 265-275.

Giovanni Pico della Mirandola. Oratio de hominis dignitate (Mowa o godności człowieka). Przeł. Z. Nerczuk i M. Olszewski. Warszawa: Wydawnictwo IfiS PAN, 2010.

Gruchała, Janusz S. „Biernata z Lublina antologia filozoficzna z początku XVI w. (Hermes Trismegistos - Platon - Arystoteles)". Biuletyn Biblioteki Jagiellońskiej XXXVIII (1988). S. 63-81.

Hajdukiewicz, Leszek. Biblioteka Macieja z Miechowa. Wrocław: Zakład Narodowy im. Ossolińskich. Wydawnictwo Polskiej Akademii Nauk, 1960.

Hugo de St. Victore. Didascalicon de studio legendi. Studienbuch, lateinisch-deutsch. Ed. Thilo Offfergeld. Freiburg - New York: Herder, 1997.

Jonas, Hans. Religia Gnozy. Przeł. M. Klimowicz. Liszki: Wydawnictwo Platan, 1994.

Kristeller, Paul Oscar. „Myśl moralna humanizmu renesansowego”. Przeł. Maciej Szymański. Paul Oscar Kriseller. Humanizm i filozofia. Cztery studia. Red. Lech Szczucki. Warszawa: Polska Akademia Nauk Instytut Filozofii i Socjologii, 1985. S. 89-149.

Lucentini, Paolo. „L'Asclepius ermetico nel secolo XII”. From Athens to Chartres. Neoplatonism and Medieval Thought. Studies in Honour of Edouard Jeauneau. Ed. Édouard Jeauneau, Haijo Jan Westra. Leiden-New York-Koeln: E. J. Brill, 1992. S. 397-420.

Lucentini Paolo, Compagni Perrone Vittoria. I testi e i codici di Ermete nel Medioevo. Firenze: Edizioni Polistampa, 2001.

Mikołaj z Kuzy. O oświeconej niewiedzy. Przeł. I. Kania. Warszawa: Wydawnictwo Aletheia, 2014.

McKnight, Stephen A. The Modern Age and the Recovery of Ancient Wisdom. A Reconsideration of Historical Consciousness, 1450 - 1650. Columbia - London: University of Missouri Press, 1991.

Moreschini, Claudio. Hermes Christianus. The Intermingling of Hermetic Piety and Christian Thought. Transl. P. Backer. Turnhout: Brepols, 2011.

Nowicka-Jeżowa, Alina. „Nurty humanistyczne w kulturze polskiej. Perspektywy historii idei”. Humanitas. Projekty antropologii humanistycznej. Paradygmaty - tradycje - profile historyczne. Red. A. Nowickiej-Jeżowej. T. 1. Warszawa: Wydawnictwo Neriton 2009- 2010. S. 11-135.

Pawlak, Wiesław. "Z dziejów pojęcia humanitas (do wieku XVII)". Humanitas. Projekty antropologii humanistycznej. Paradygmaty - tradycje - profile historyczne. Red. A. Nowickiej-Jeżowej. T. 1. Warszawa: Wydawnictwo Neriton 2009-2010. S. 165-204.

Platon. „Timajos”. Platon. Dialogi. Przeł. Władysław Witwicki. Warszawa: Unia Wydawnicza "Verum” 2012. S. 297-366.

Porreca, David. „Albert the Great and Hermes Trismegistus: An Update". Mediaeval Studies 72 (2010). S. $245-281$

Pseudo-Apulejusz. „Asklepiusz, czyli rozmowa z Hermesem Trismegistosem”. Apulejusz z Madaury, O Bogu Sokratesa. O Platonie i jego nauce. O świecie. Przełożył, komentarzem opatrzył i wstępem poprzedził Kazimierz Pawłowski.Warszawa: Wydawnictwo Naukowe PWN, 2002. S. 173-219.

Scott, Walter ed. Hermetica. The Ancient Greek and Latin Writings which Contain Religious or Philosophic Teachings Ascribed to Hermes Trismegistos. Introduction, translation and notes W. Scott. Vol. 1-4. Boston: Shambhala 1985a-d.

Taylor, Jerome. „Notes”. Hugh of Saint Victor. The Didascalicon. Transl. and intro. Jerome Taylor. New York: Columbia University Press, 1991 (ed. I, 1961). S. 158-228.

Thomas, Paul ed. "Asclepius". Apulei Platonici Madaurensis opera quae supersunt. Vol. 3. Lipsiae: B. G. Teubner, 1921. S. 36-81.

Ziomek, Jerzy. „Wstęp”. Biernat z Lublina. Wybór pism. Wrocław: Biblioteka Narodowa. Seria I. Nr 149, 1953. S. V-CIII. 